\title{
Prodrugs of Antiinfective Agents: A Review
}

\author{
Mona Piplani, Avtar Chand Rana, Prabodh Chander Sharma \\ Institute of Pharmaceutical Sciences, Kurukshetra University, Kurukshetra, India
}

Received, October 18, 2015; Revised, November 17, 2015; Accepted, January 30, 2016; Published, February 8, 2016

\begin{abstract}
Purpose. Prodrugs are the pharmacologically inactive derivatives of active drugs typically intended to optimize the exposure of active drug at target site, through manipulation of its physicochemical, biopharmaceutical or pharmacokinetic properties. This approach has a number of advantages over conventional drug administration. Antiinfective agents are associated with number of limitations, responsible for their reduced bioavailability. Various antiinfective prodrugs have been synthesized with reduced side effects and improved pharmacological properties. The present paper illustrates different vistas of prodrug approach of antiinfective agents describing brief classification, synthetic approaches, pharmacological aspects and recent patents. It is a very productive area of research and its prologue in human therapy has given triumphant outcomes in improving the clinical and therapeutic effectiveness of drugs.
\end{abstract}

This article is open to POST-PUBLICATION REVIEW. Registered readers (see "For Readers") may comment by clicking on ABSTRACT on the issue's contents page.

\section{INTRODUCTION}

Infection is the sequential event that starts from the invasion of pathogens in body tissues of host, followed by their multiplication, response of host tissues to these pathogens along with toxin produced by them (1). Scientific literature and medical experience indicate that microbial infection is one of the prime dangers to human life and World Health Organization considered it as leading cause of human death worldwide $(2,3)$. As per available reports, infections caused by pathogenic viruses, bacteria, fungi and parasites account for millions of deaths per year $(4,5)$.

The use of anti-infective agents are credited with saving more human lives than any other area of medicinal therapy discovered to date $(6,7)$. Though antiinfective agents are being used for treatment of infectious disorders for last several decades, these are associated with some undesirable properties such as poor bioavailability, high first pass metabolism, toxicity, local irritation, incomplete absorption, poor aqueous solubility, lipophilicity, etc. as represented in Figure 1 (8-12).

Therefore, there is great emphasis on research to find out methods aimed at improving their desired characteristics [13-15]. The term "prodrug" or "proagent" was introduced by Albert to describe active pharmaceutical agents that undergoes biotransformation prior to elicit their pharmacological effects (16). Prodrug strategies consist of a transient modification of the physicochemical properties of a given compound through chemical derivatization. Such reversible

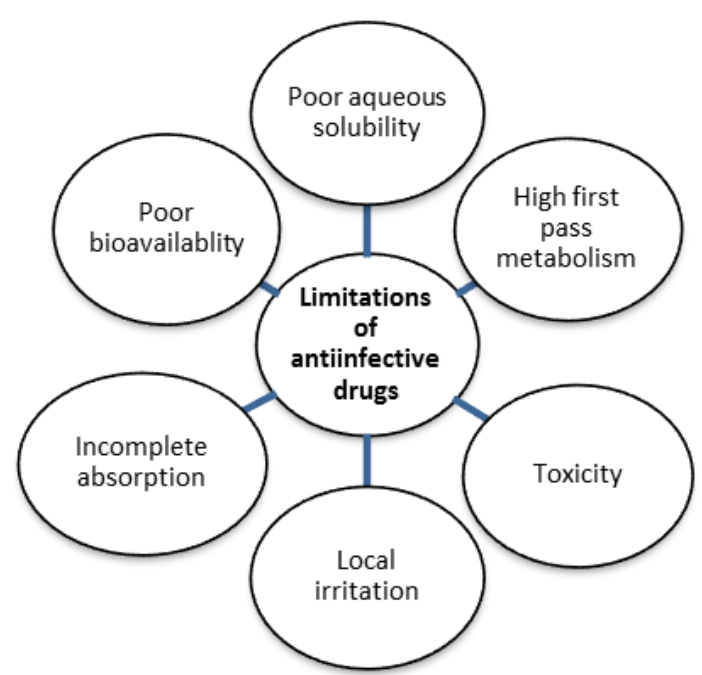

Figure 1. Various limitations of available antiinfective drugs.

Correspondence Author: Dr. Prabodh Chander Sharma, Institute of Pharmaceutical Sciences, Kurukshetra University, Kurukshetra-136119, Haryana, India. Email: sharma_prabodh@rediffmail.com 
chemical modification is designed to augment chemical stability, alter aqueous solubility, or improve bioavailability while the intrinsic pharmacological properties of the parent drug remain intact (17-21). A very good indication of the success of prodrug approach can be observed by examining the prevalence of prodrugs in the market.
A few marketed antiinfective prodrugs are given in Table 1 (15,17,22-25).

Prodrugs are classified into carrier linked and bioprecursors on the basis of the way they release the active drug. Classification of prodrugs has been represented in Figure 2 (26-29).

Table 1. Marketed antiinfective prodrugs

\begin{tabular}{llll}
\hline Category & Prodrug & Parent drug & Trade name \\
\hline Antiviral & Valacyclovir & Acyclovir & Valtrex \\
Antiviral & Famciclovir & Penciclovir & Famvir \\
Antibacterial & Tedizolid phosphate & Tedizolid & Sivextro \\
Antiherpes simplex B virus & Adefovir dipivoxil & Adefovir & Preveon \\
Antibacterial & Bacampicillin & Ampicillin & Bacacil \\
Antiretroviral & Tenofovir disoproxil & Tenofovir & Viread \\
Antiretroviral & Fosamprenavir & Amprenavir & Lexiva \\
Antiviral & Fludarabine phosphate & Fludarabine & Fludara \\
Antifungal & Fosfluconazole & Fluconazole & Procif \\
Antiviral & Oseltamivir & Oseltamivir & Tamiflu \\
& & carboxylate & \\
\hline
\end{tabular}

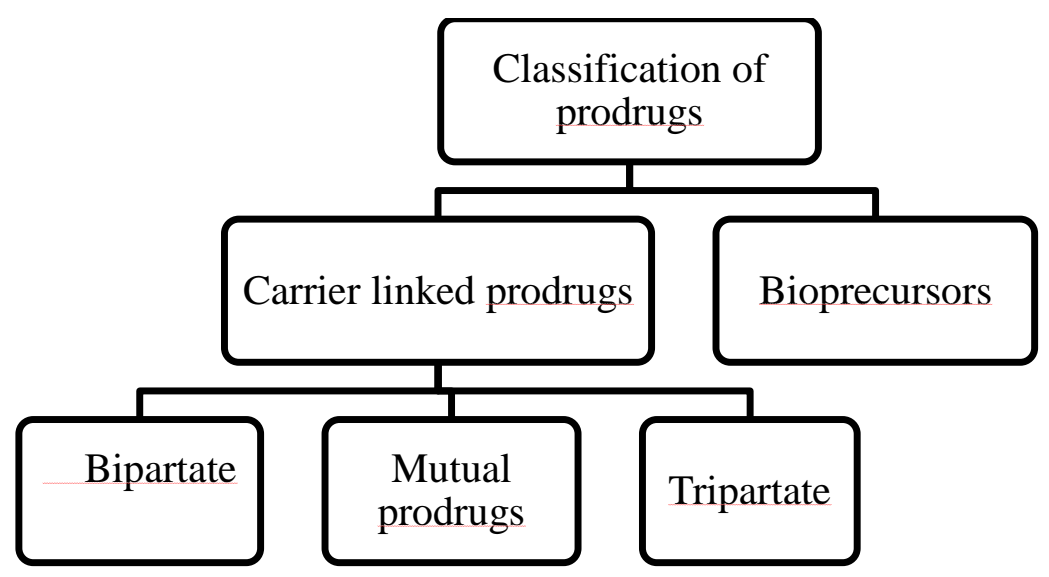

Figure 2. Classification of prodrugs

Limitations associated with various antiinfective agents and successful implementation of prodrug approach for a variety of medicinally active agents has encouraged the researchers to synthesize prodrugs of antiinfective agents. A number of scientific papers have been published in last 3-4 decades. In this article, we have attempted to review the prodrugs of antiinfecive agents and summarize the triumph of prodrugs in achieving their improved pharmacokinetic parameters. This paper also discusses briefly general aspects of prodrug design and some recent patents of antiinfective prodrugs. 


\section{ANTIINFECTIVE ACTIVITY PROFILE OF VARIOUS PRODRUGS}

Herein we describe some important synthesized prodrugs with antiinfective activities reported in literature of last few decades.

\section{Prodrugs of Antibacterial Agents}

Antibiotics are low molecular weight compounds produced by microorganisms and are active against pathogenic microorganisms (30). Treatment of infectious disorders depends upon several factors such as interactions among pathogens, facts related to host, physicochemical features of antimicrobial agents, its pharmacokinetics and pharmacodynamics. Infectious disorders caused by bacteria are the prime cause of mortality, affecting millions of people. Keeping in view the severity of these types of infections, continuous efforts for search of novel antibacterial agents are undertaken. In addition to search of novel antimicrobial agents, modification of existing drugs is a field of current and growing interest $(31,32)$. Several attempts have been made to synthesize novel prodrugs of antibacterial agents.

Prodrug approach has been adopted for synthesis and evaluation of a series of amino acid and dipeptide prodrugs of IMB-070593, 1 by Zhang et al. Due to greater water solubility, compounds 2 and 3 were found to exhibit 1.19-1.50 fold high antibacterial activity against methicillin-sensitive $S$. aureus and S. pneumonia than the parent drug (28).<smiles>CO/N=C1/CCN(c2c(F)cc3c(=O)c(C(=O)O)cn(C4CC4)c3c2OC)CC1N</smiles><smiles>CO/N=C1\CCN(c2c(F)cc3c(=O)c(C(=O)O)cn(C4CC4)c3c2OC)CC1NC(=O)CNC(=O)CN</smiles>

IMB-070593, 1<smiles>CO/N=C1\CCN(c2c(F)cc3c(=O)c(C(=O)O)cn(C4CC4)c3c2OC)CC1NC(=O)CN</smiles>

3

New derivatives of ceftazidime as possible prodrug were synthesized by Alwan et al. The compounds $\mathbf{4}$ and $\mathbf{5}$ showed reasonable antibacterial activities against $\mathrm{G}(+)$ Streptococcus species in comparison with ceftazidime, having no activity against these types of microorganisms (33).

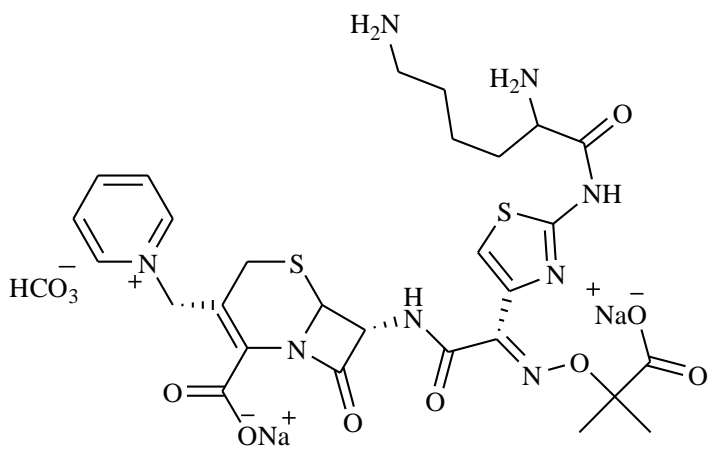

4

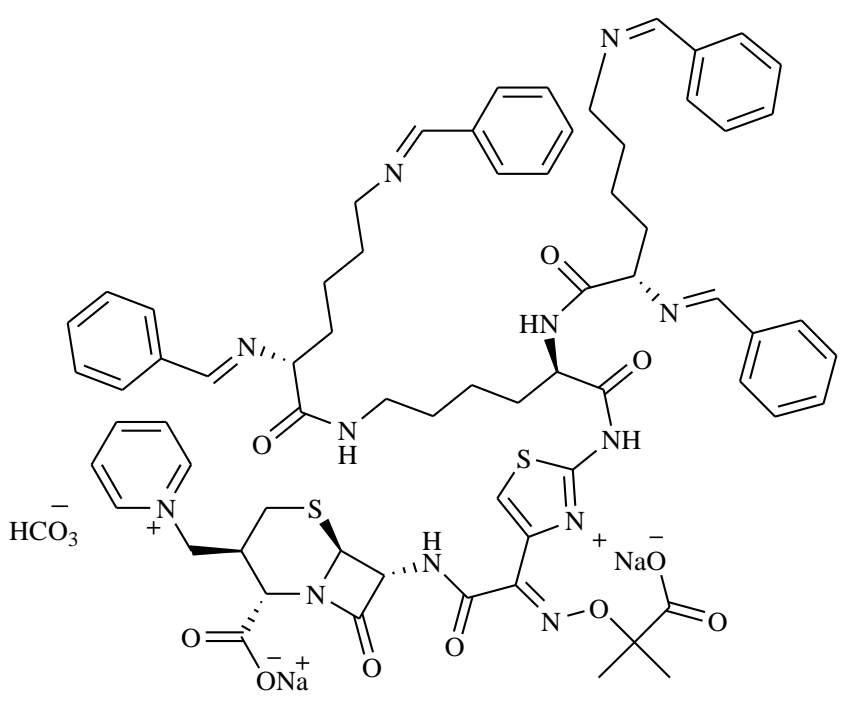


Prodrug approach was adopted using diglyceride as a promoiety to improve bioavailability of poorly absorbed drug, norfloxacin; a second generation fluoroquinolone antibacterial by Dhaneshwar et al. The prodrug 6 has been synthesized by standard procedures using dipalmitine as a carrier and found to exhibit improved pharmacological profile than the parent compound at equimolar dose that indirectly indicated improved bioavailability (9).

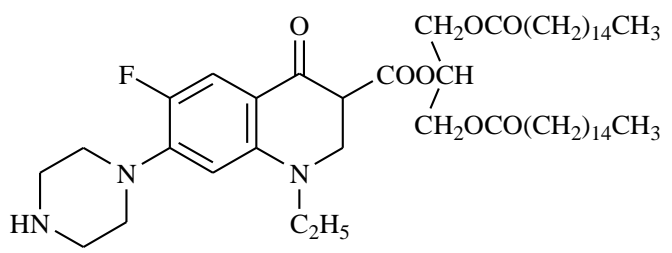

6

Dubey et al have synthesized and evaluated various novel aromatic and aliphatic esters of metronidazole to improve the physicochemical properties (Rm values, lipophilicity) using prodrug approach. The synthesized compounds $\mathbf{7}$ and $\mathbf{8}$ were found to be more potent in terms of MIC $(\mu \mathrm{g} / \mathrm{mL})$ against $C$. Perfringens in comparison to metronidazole due to enhanced lipophilicity (10).<smiles>[R]C(=O)OCCn1c([N+](=O)[O-])cnc1C</smiles>

Abdul-Kadir et al prepared cyclic amine derivatives of metronidazole using acetate spacer. These derivatives showed better physicochemical and biological properties. As per studies, the compound 9 can be utilized on its own as effective mutual prodrug without requirement of any drug in connection (34).

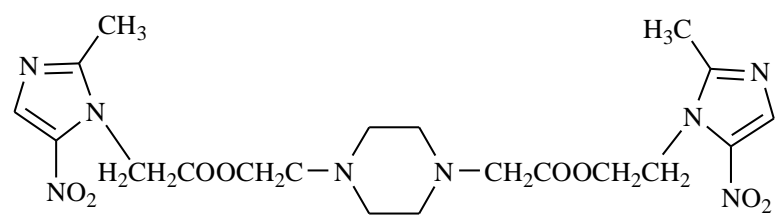

9
Dibama et al carried out drug release studies and investigated antibacterial behavior of a watersoluble nalidixic acid/calix[4]arene ester adduct $\mathbf{1 0}$. In vitro antibacterial evaluation showed that the title compound was efficient on one Gram-negative $(E$. coli) and two Gram-positive ( $S$. aureus) reference strains, with a clear gain of activity when compared to its two hydrolysis by-products (11).

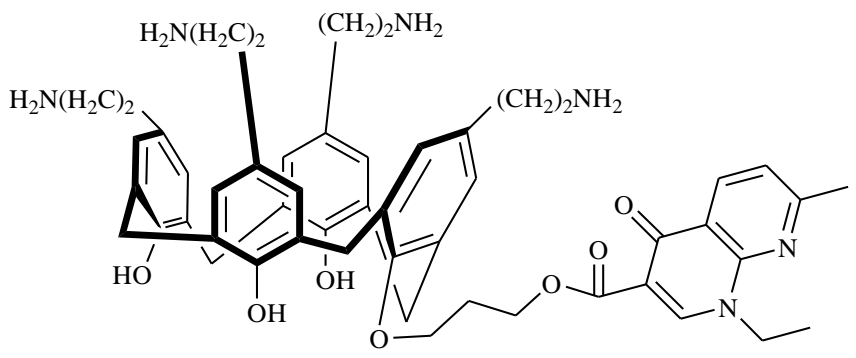

10

Sobczak et al developed and carried out structural analysis of polyester prodrugs of norfloxacin. The two, three and four arm star shaped poly( $\varepsilon$-caprolactone) and poly(D,L-lactide) homopolymers and copolymers of $\varepsilon$-caprolactone with $\mathrm{D}, \mathrm{L}$ lactide were used for synthesis of norfloxacin polyester prodrugs. The synthesized polyester prodrugs, $\mathbf{1 1}$ were proved to be good potential candidates to be used as drug delivery carriers (35).<smiles>CCCOOC(=O)C1=CC(CC)c2cc(N3CCNCC3)c(F)cc2C1=O</smiles>

11

Yar et al synthesized macromolecule conjugate of hydroxypropyl methacrylamideofloxacin, 12. They found that covalent linkage of ofloxacin to a biocompatible polymer, poly (hydroxypropyl methacrylamide), via the ester group leads to a delivery system which is capable of releasing the drug in a sustained manner over the gastrointestinal tract and ultimately increased $t_{1 / 2}$ of the drug (36). 


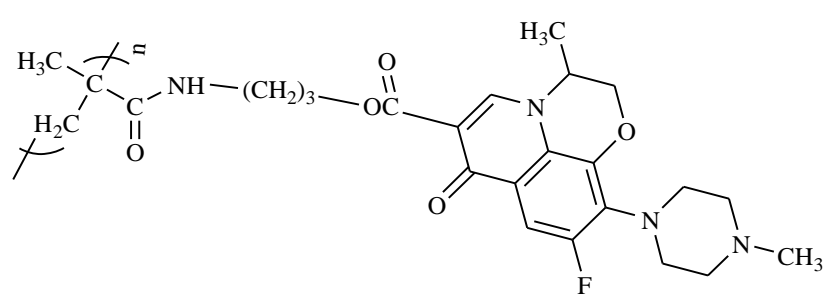

12

Isoda et al synthesized various prodrug esters and carried out their pharmacokinetic studies. Oral carbapenem antibiotic L-084, 13 was found to exhibit high bioavailability and $\mathrm{C}_{\max }$ in humans. Compound 13 showed a strong antimicrobial activity against Gram-positive and Gram-negative bacteria and exhibited the highest intestinal absorption among synthesized prodrugs of $(1 R, 5 S, 6 S)-6-[(R)-1$-hydroxyethyl]-1-methyl-2-[1(1,3-thiazolin-2-yl) azetidin-3-yl] thio-1-carbapen2-em-3-carboxylic acid (37).

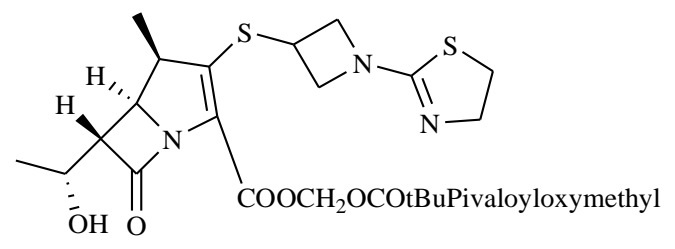

\section{3}

A novel series of flavonyl pro-drug esters of ampicillin was synthesized and evaluated for antimicrobial properties by ÜnlÜsoy et al. The synthesized compounds were tested for their antifungal and antibacterial activities in vitro and compound 14 was reported to have high activity against $S$. aureus $(33 \mathrm{~mm})$ comparable with ampicillin (38).

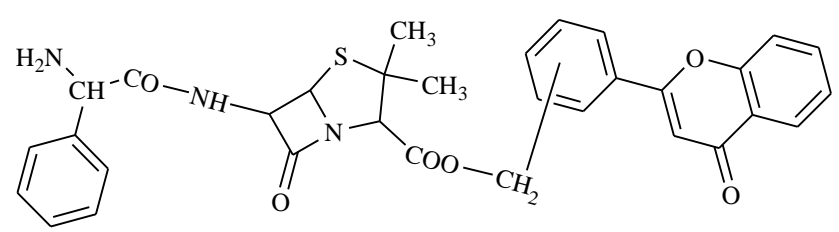

\section{4}

Mishra et al synthesized different curcumin bioconjugates viz. 4,4'-di- $O$-glycinoyl-curcumin $\mathbf{1 5}$, 4,4'-di- $O$-(glycinoyl-di-N-piperoyl)-curcumin $\mathbf{1 6}$, 4,4'-di- $O$-D-alaninoylcurcumin $\quad \mathbf{1 7}, 4,4^{\prime}-\mathrm{di}-O$ piperoyl curcumin 18, curcumin-4,4'-di- $O-\beta$-Dglucopyranoside 19, 4,4'-di- $O$-acetyl-curcumin $\mathbf{2 0}$ along with piperoyl glycine. The compound $\mathbf{1 6}$ and
20 were found to be more effective as compared to cefepime, an antibacterial drug existing in market, at the equivalent concentration. The compound $\mathbf{1 6}$ and 18 had antifungal activity in vitro almost comparable with fluconazole, the most accepted antifungal drug. The escalated activity of these bioconjugates compared to the parent molecule, curcumin may be due to improved cellular uptake or reduced metabolism of these bioconjugates resulting in building up of enough concentration inside the infected cells (39).<smiles>COc1ccc(/C=C/C(=O)CC(=O)/C=C/c2ccc(O)c(OC)c2)cc1O</smiles>

15: $\mathrm{R}=\angle \mathrm{CO}-\mathrm{CH}_{2}-\mathrm{NH}_{2}$

17: $\mathrm{R}=$<smiles>CC(N)OC(C)N</smiles>

16: $\mathrm{R}=$

18: $\mathrm{R}=$

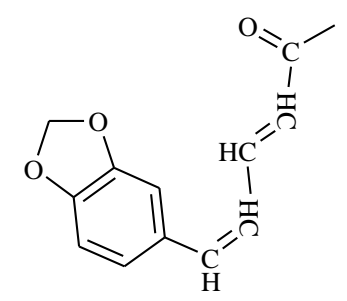<smiles></smiles>

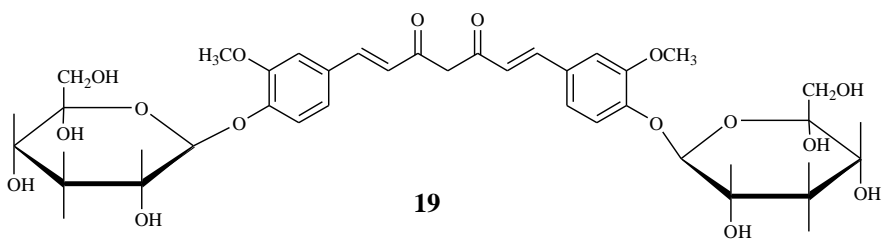<smiles>COc1cc(/C=C/C(=O)CC(=O)/C=C/c2ccc(OC(C)=O)c(OC)c2)ccc1OC(C)=O</smiles> 
Hakimelahi designed, synthesized and evaluated two novel carbapenems trans-3hydroxycarbonyl- 6-(phenylacetamido)carbapenem ( \pm ) 21 and trans-3- phosphono-6-(phenylacetamido) carbapenem $( \pm) 22$ for biological activity. Carbapenem 21 was found to possess antibacterial activity, comparable with imipenem (+)-23, against $S$. aureus FDA 209P, E. coli ATCC 39188, K. pneumonia NCTC 418, P. aeruginosa $1101-75$ as well as the $\beta$-lactamase producing organism $P$. aeruginosa $18 \mathrm{~S}-\mathrm{H}$ and methicillin resistant organism $S$. aureus 95. On combining trans carbapenem 21 with cis carbapenem, compound $\mathbf{2 4}$ as well as clavulanic acid, $\mathbf{2 5}$ with cis carbapenem compound $\mathbf{2 6}$ via a tetrachloroethane linker exhibited remarkable activity against $\beta$-lactamase producing microorganisms in vitro (40).

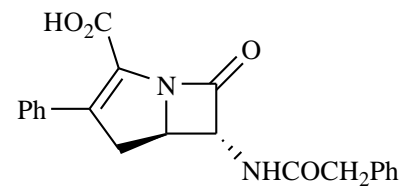

21

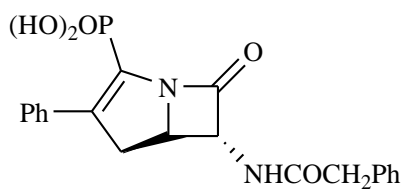

22<smiles>C[C@H](O)[C@H]1C(=O)N2C(C(=O)O)=C(SCNC=N)C[C@H]12</smiles>

23<smiles>CC(=O)C1=C(C(=O)OC(Cl)(Cl)C(Cl)(Cl)OC(=O)C2=C(c3ccccc3)C[C@@H]3[C@H](NC(=O)OCc4ccccc4)C(=O)N23)N2C(=O)[C@H](NC(=O)OCc3ccccc3)[C@H]2C1</smiles>

24<smiles>O=C(O)/C=C1/OC2CC(=O)N2C1CO</smiles>

25<smiles>[CH]C(=O)N[C@H]1C(=O)N2C(C(=O)OC(Cl)(Cl)C(Cl)(Cl)OC(=O)[C@H]3/C(=C\CO)O[C@@H]4CC(=O)N43)=C(C(C)=O)C[C@H]12</smiles>

26

Four potential prodrugs of 3'-azido-3'deoxythymidine (AZT), 27-30 with improved lipophilicity were synthesized and evaluated by Moroni et al. The 5'-OH group of 3'-azido-3'deoxythymidine was functionalized with oxalyl chloride obtaining an acyl chloride derivative, which by further transformation with leucine, isoleucine and valine amino acids led to the corresponding AZT analogs, namely AZT-Leu, AZT-iLeu and AZT-Val. The most effective antibacterial drug AZT-Leu, (M.I.C. $=0.125 \mu \mathrm{gmL}^{-}$ ${ }^{1}$ ) was found to be sixteen times more active than AZT (AZT, M.I.C. $=2 \mu \mathrm{g} \mathrm{mL}^{-1}$ ) against $K$. pneumoniae ATCC 10031. The activity order for the studied compounds against the most sensitive strain (K. pneumoniae ATCC 10031) was found to be AZT-Leu > AZT-iLeu > AZT-Val > AZT-Ac > AZT (41).<smiles>[R]C(=O)C(=O)OCC1OC(n2cc(C)c(=O)[nH]c2=O)CC1N</smiles>

Chemical structure of zidovudine analogs (27-30)

\begin{tabular}{ll}
\hline Compounds & R \\
\hline AZT-Leu,27 & $\mathrm{NHCH}(\mathrm{COOH}) \mathrm{CH}_{2} \mathrm{CH}\left(\mathrm{CH}_{3}\right)_{2}$ \\
AZT-iLeu,28 & $\mathrm{NHCH}(\mathrm{COOH}) \mathrm{CH}_{2}\left(\mathrm{CH}_{3}\right)_{\mathrm{CH}_{2} \mathrm{CH}_{3}}$ \\
AZT-Val,29 & $\mathrm{NHCH}(\mathrm{COOH}) \mathrm{CH}\left(\mathrm{CH}_{3}\right)_{2}$ \\
AZT-Ac,30 & $\mathrm{OH}$
\end{tabular}




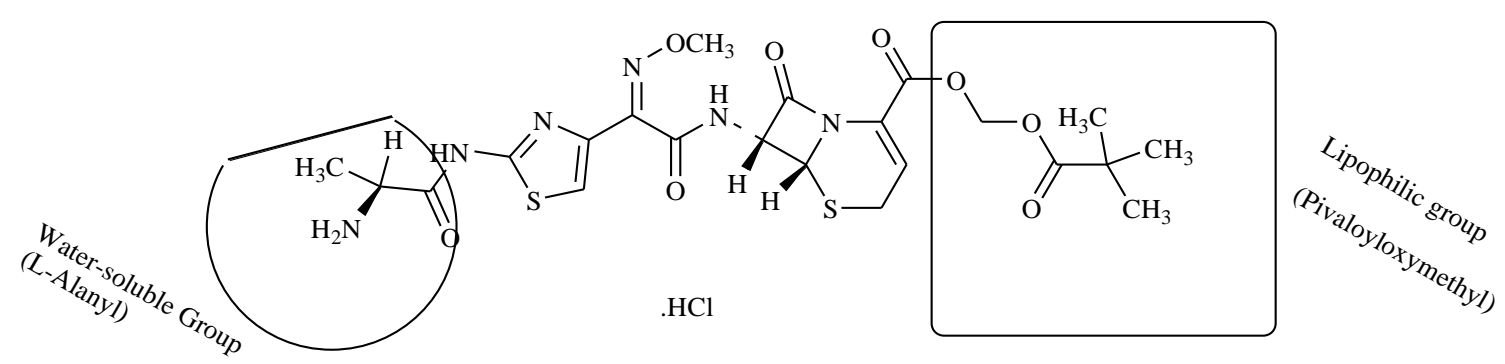

31

Mori et al designed and developed a novel prodrug 31, AS-924, by esterifying ceftizoxime with a lipophilic pivaloyloxymethyl (POM) group and introducing a water soluble L-alanyl group. As AS-924 was found to have a good balance of lipophilicity and water solubility, it could be clinically expected that the synthesized prodrug, when administered orally, would be absorbed well and consequently show good clinical efficacy (42).

Wei et al synthesized 5'-dipeptidyl derivatives of 5-fluorodeoxyuridine (FdU), 32-35. These prodrugs were found to be biologically inactive but could be activated by peptide deformylase. Because the deformylase is ubiquitous among bacteria but absent in mammalian cells, these prodrug compounds provided a novel class of potential antibacterial agents (43).<smiles>CNC(C(=O)NC=O)C(=O)NC(C)C(=O)OCC1OC(n2cc(F)c(=O)[nH]c2=O)CC1O</smiles>

32: $\mathrm{R}_{1}, \mathrm{R}_{2}=\mathrm{CH}_{2} \mathrm{CH}_{2} \mathrm{CH}_{2}, \mathrm{R}_{3}=\mathrm{H}$ 33: $\mathrm{R}_{1}, \mathrm{R}_{3}=\mathrm{CH}_{2} \mathrm{CH}_{2} \mathrm{CH}_{2}, \mathrm{R}_{2}=\mathrm{H}$ 34: $\mathrm{R}_{1}=\mathrm{CH}_{3}, \mathrm{R}_{2}=\mathrm{CH}_{2} \mathrm{CH}\left(\mathrm{CH}_{3}\right)_{2}, \mathrm{R}_{3}=\mathrm{H}$ 35: $\mathrm{R}_{1}=\mathrm{H}, \mathrm{R}_{2}=\mathrm{R}_{3}=\mathrm{CH}_{3}$

In order to illuminate the minimum structural requirements for antibacterial activity and in search of compounds with good bioavailability Evans et al synthesized totarol derivatives and evaluated their antibacterial activity. Amongst the synthesized prodrugs, totaryl $\alpha$-D-mannopyranoside $\mathbf{3 6}$ proved the most active in vitro (MIC $18 \mathrm{mM}$ ) against three Gram positive bacteria: $\beta$-lactamase positive and high level gentamycin resistant E. faecalis, penicillin resistant $S$. pneumoniae and methicillin resistant $S$. aureus (44).

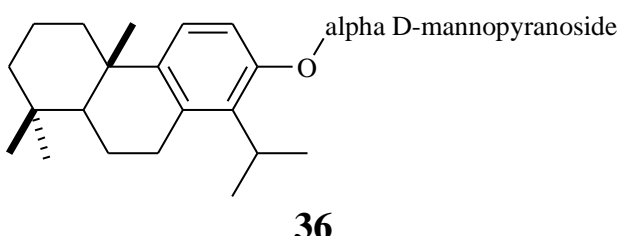

Bowden et al designed and synthesized a series of chain and cyclic acylbenzoate esters of metronidazole. The esters were designed to be both lipophilic and reactive in their hydrolysis reactions. The first series was composed of acylbenzoate esters of metronidazole 37-43, and the second series was composed of the cyclic (pseudo) 2formylbenzoate esters $\mathbf{4 4 , 4 5}$ i.e. 3 -alkoxyphthalides. The antibacterial activity of these esters was found to be comparable to that of metronidazole (45).<smiles>[X]c1ccc(C(=O)O[14CH2]n2c([N+](=O)[O-])cnc2C)cc1</smiles>
37: $\mathrm{X}=\mathrm{H}$,
38. $\mathrm{X}=2-\mathrm{CHO}$,
41. $\mathrm{X}=2-\mathrm{C}(\mathrm{O}) \mathrm{CH}_{3}$
39: $\mathrm{X}=4-\mathrm{CHO}$,
42: $\mathrm{X}=2-\mathrm{C}(\mathrm{O}) \mathrm{CF}_{3}$
40: $\mathrm{X}=2-\mathrm{C}(\mathrm{O}) \mathrm{C}(\mathrm{O}) \mathrm{Ph}$
43: $\mathrm{X}=2,6(\mathrm{CHO})_{2}$<smiles>[X]c1cccc2c1C(OC#CCn1c([N+](=O)[O-])cnc1C)OC2=O</smiles>

44: $\mathrm{X}=\mathrm{H}$,

45: $\mathrm{X}=\mathrm{CHO}$ 


\section{Prodrugs of Antitubercular Agents}

Tuberculosis is one of the major public health concerns globally, caused by Mycobacterium tuberculosis (46). It has been reported by WHO that 9 million people suffered illness and 1.5 million died due to tuberculosis in year 2013 alone (47).

In recent years, tuberculosis is on the increase principally due to HIV infection, immigration, increased trade and globalization (48). Therefore, it is an urgent task to develop new derivatives or formulations of antitubercular drugs acting on novel drug targets to enhance stability, half life as well as oral bioavailability.

Fernandes et al synthesized pyrazinoic acid prodrug, 2-chloroethyl pyrazinoate, $\mathbf{4 6}$ and evaluated it for its activity in Mycobacterium tuberculosis $\mathrm{H}_{37} \mathrm{Rv}$ (ATCC27294) in minimal inhibitory concentration (MIC) assay using the microplate Alamar blue assay technique. The obtained MIC of the synthesized prodrug was found to be $3.96 \mathrm{~g} / \mathrm{mL}$, proved better than pyrazinamide (reported MIC 50-100 g/mL) (49).

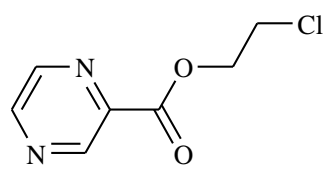

46

Several alkyloxycarbonyloxyalkyl ester prodrugs of meropenem were synthesized and evaluated in an effort to improve the lipophilicity as well as oral absorption of the parent carbapenem by Teitelbaum et al. Their stability in physiological aqueous solutions and guinea pig as well as human plasma was evaluated. The prodrugs containing the 2-benzosuberyl, 2-tetralyl, and 2-indanyloxycarbonyloxymethyl promoieties, 47-49 respectively were found to be significantly more stable at physiological pH 7.4 and intestinal pH 6.0. In simulated gastric fluid $(\mathrm{pH}$ 1.2), these compounds degraded to form the ring-opened prodrug metabolite (50).

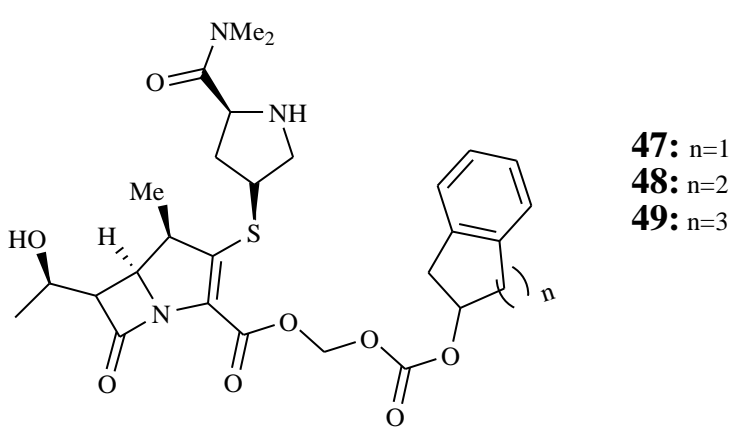

Cassano et al synthesized, characterized and carried out in vitro antitubercular activity of isoniazid-gelatin conjugate, 50. Spectrophotometric analysis revealed that the protein derivative was an excellent isoniazid prodrug since there was a $40 \%$ reduction in release of toxic metabolites (isonicotinic acid) by the prodrug and the compound $\mathbf{5 0}$ showed significant antitubercular activity (12).<smiles>NCC(=O)NNC(=O)c1ccncc1</smiles>

50: where $\mathrm{G}=$ gelatin

Uh et al synthesized a series of lipophilic, prodrug analogs of fosmidomycin, $\mathbf{5 1}$ and FR900098, 52, inhibitors of the nonmevalonate pathway enzyme, 1-deoxy-D-xylulose-5-phosphate reductoisomerase. Several of these compounds 5356 were found to show improved antibacterial activity against a panel of organisms relative to the parent compound, including better activity of compounds 57,58 as compared to $\mathbf{5 4 - 5 6}$ against Mycobacterium tuberculosis (51).

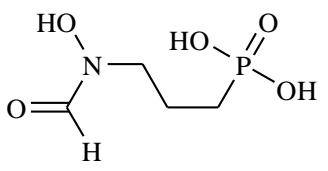

51

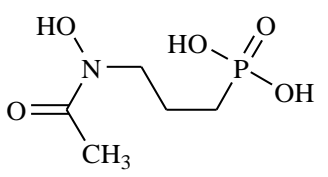

52 
<smiles>[Z10]OP([R9])(=O)CCCN(O)C([R])=O</smiles>

Lipophilic ester of $51 \& 52$

\begin{tabular}{ccc}
\hline Compounds & $\mathbf{R}$ & $\mathbf{R}_{\mathbf{1}}$ \\
\hline $\mathbf{5 3}$ & $\mathrm{CH}_{3}$ & $-\mathrm{CH}\left(\mathrm{CH}_{3}\right) \mathrm{OCOOC}\left(\mathrm{CH}_{3}\right)_{3}$ \\
$\mathbf{5 4}$ & $\mathrm{H}$ & $\mathrm{Et}$ \\
$\mathbf{5 5}$ & $\mathrm{CH}_{3}$ & $\mathrm{Et}$ \\
$\mathbf{5 6}$ & $\mathrm{CH}_{3}$ & $i \mathrm{Pr}$ \\
$\mathbf{5 7}$ & $\mathrm{CH}_{3}$ & $-\mathrm{CH}_{2} \mathrm{OCOC}_{\left(\mathrm{CH}_{3}\right)_{3}}$ \\
$\mathbf{5 8}$ & $\mathrm{CH}_{3}$ & $-\mathrm{CH}_{2} \mathrm{OCOC}_{6} \mathrm{H}_{5}$
\end{tabular}

Qasir et al designed and developed mutual prodrug (PAS-Gly-INH), 59 of p-amino salicylic acid (PAS) and isoniazid (INH), with improved physicochemical properties. The synthesized compound showed better partition coefficient and hence expected for better absorption compared with the original apromoiety (PAS, INH) (52).

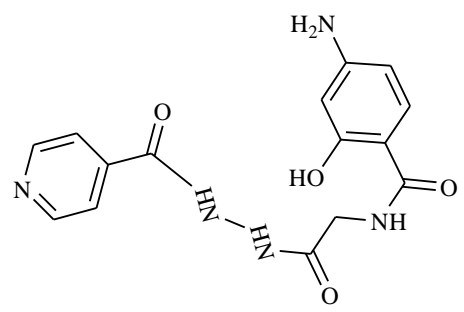

59

Meng et al reported a novel series of prodrugs of SQ109, 60. The parent drug, 60 released from the synthesized prodrug, $\mathbf{6 1}$ after oral administration exhibited preferential tissue distribution into lung and spleen, the target organs of tubercular infection and replication (53).<smiles>CC(C)=CCC/C(C)=C/CNCCNC1C2CC3CC(C2)CC1C3</smiles>

60<smiles>CC(C)=CCCC(C)=CCN(CCNC1C2=C(C(=O)O)CC3CC(CC1C3C)C(C(=O)O)C2)C(=O)OCC(=O)O</smiles>

61

Mutual prodrugs of isoniazid, $p$-amino salicylic acid and ethambutol were synthesized and evaluated by Rawat et al. The results revealed that mutual prodrugs PI (isoniazid with p-amino salicylic acid), $\mathbf{6 2}$ and PE (ethambutol with p-amino salicylic acid), 63 significantly eliminate the problem of fast metabolism, toxicity and local irritation and reduction of therapeutic doses (54).<smiles>Nc1ccc(C(=O)NNC(=O)c2ccncc2)c(O)c1</smiles>

62<smiles>CCC(CCO)NCCNC(CC)CCOC(=O)c1ccc(N)cc1O</smiles>

63

Roseeuw et al carried out synthesis, degradation and studied antimicrobial properties of targeted macromolecular prodrugs of norfloxacin. In Gly-Phe-Gly-Gly ( $\alpha$-norfloxacin)-OMe, 64 norfloxacin was linked to the carrier through an alpha bond. They demonstrated that targeting by using mannose as a homing device was required to achieve antimycobacterial activity in vivo (55).

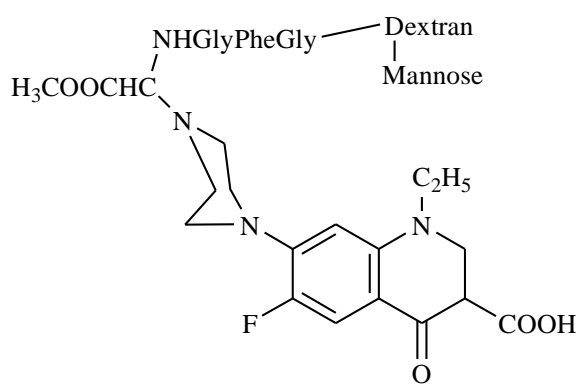

64 
Cycloserine (seromycin, 4(R)-amino-3isoxazolidinone), a well-known drug used for the treatment of tuberculosis and certain genitourinary infections, especially when caused by Enterobacteria or E. coli. Systemic side effects check the usage of cycloserine and topical application or local delivery has restricted value because cycloserine is a highly water-soluble compound and inadequately permeable through lipophilic membranes such as the skin. Thorsteinsson et al synthesized various 4,5dihydroisoxazol-3-yl fatty acid ester derivatives of cycloserine, 65-68 to improve skin permeation of cycloserine. The ester derivatives were synthesized using the tert-butoxycarbonyl ( $t$-Boc) protection strategy. The skin permeation of cycloserine across the hairless mouse skin was reported to increase up to 20 -fold by the fatty acid esters (56).<smiles>[R]C(=O)OC1=NOC[C@H]1N</smiles>

65: $\mathrm{R}=\mathrm{CH}_{3}$

66: $\mathrm{R}=\left(\mathrm{CH}_{2}\right)_{6} \mathrm{CH}_{3}$

67: $\mathrm{R}=\left(\mathrm{CH}_{2}\right)_{7} \mathrm{CH}=\mathrm{CH}\left(\mathrm{CH}_{2}\right)_{7} \mathrm{CH}_{3}$

68: $\mathrm{R}=\left(\mathrm{CH}_{2}\right)_{7} \mathrm{CH}=\mathrm{CH}\left(\mathrm{CH}_{2}\right)_{7} \mathrm{CH}_{3}$

\section{Prodrugs of Anitmalarial Agents}

Malaria is a potentially lethal tropical disorder, spread by mosquitoes and its causative agent is protozoan parasites of the genus Plasmodium. According to latest estimates, approximately 198 million cases of malaria and 5,84000 deaths due to this diseases were observed globally in 2013 $(57,58)$. New antimalarial compounds, particularly those based on compounds structurally unrelated to existing antimalarial drugs with new mechanisms of action or prodrugs of existing compounds with modified physicochemical characteristics/ pharmacokinetic parameters are urgently needed. Davanço et al prepared and evaluated the antimalarial activity along with toxicological profile of a novel dipeptide primaquine prodrug (Phe-AlaPQ) using in vitro and in vivo assay. The prodrug was found to be more soluble in water, effective against sporogenic cycle and less toxic in a monkey kidney cell line (BGM) and human hepatoma cell line (HepG2) than the parent drug primaquine (59).
Milner et al synthesized few metabolites of ketotifen and evaluated their antimalarial activity and pharmacokinetics in mice. Norketotifen (WR621341), 69 the de-methylated metabolite of ketotifen, was found to be 15 and 8 fold more potent against Pf D6 and Pf W2, respectively, which are the two most susceptible strains of Plasmodium falciparum. They observed no toxicity with the metabolite WR621341, 69 even when dosed as high as $320 \mathrm{mg} / \mathrm{kg}$ for 3 days (60).

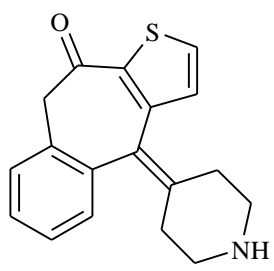

69

Caldarelli et al reported the design, synthesis, and biological screening of a series of 15 disulfide prodrugs as precursors of albitiazolium bromide (T3/SAR97276), 70, a choline analogue which is currently being evaluated in clinical trials (phase II) for severe malaria. After oral administration, the cyclic disulfide prodrug 71, showed the best improvement of oral efficacy in comparison to the parent drug (61).

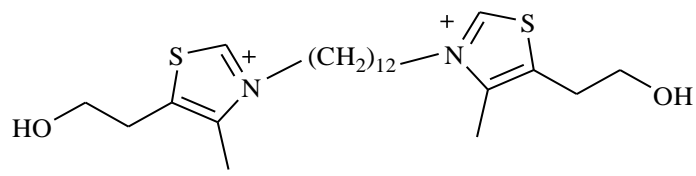

70

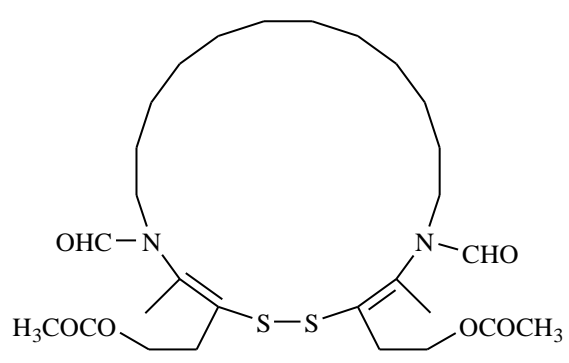

71

Dubar et al carried out the synthesis, antiparasitic evaluation and docking studies of ester prodrugs of ciprofloxacin as DNA-gyrase inhibitors. The synthesized compound $\mathbf{7 2}$ was found 
to be more active as compared to ciprofloxacin, its ethyl ester prodrug, $\mathbf{7 3}$ and the dual mettallocenic/prodrug, ferrocenyl derivative of ciprofloxacin, $\mathbf{7 4}$ against $P$. falciparum as well as $T$. gondii (62).

Dubar et al in their previous studies reported the enhancement of the antimalarial activity of ciprofloxacin using a double prodrug/ bioorganometallic approach. Two new achiral compounds $\mathbf{7 3}$ and $\mathbf{7 4}$ were found to be 10 to 100 fold more active than ciprofloxacin against Plasmodium falciparum chloroquine susceptible and chloroquine-resistant strains (63).

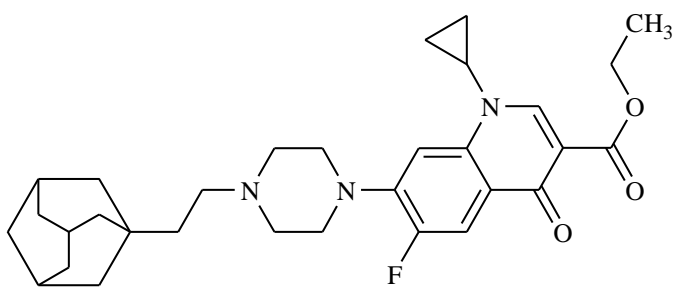

72<smiles>CCOC(=O)c1cn(C2CC2)c2cc(N3CCNCC3)c(F)cc2c1=O</smiles>

73<smiles>CCOC(=O)c1cn(Cc2ccccc2F)c2cc(N3CCNCC3)c(F)cc2c1=O</smiles>

74

New primaquine conjugates with glucosamine and two polymers of polyaspartamide type, poly $[\alpha, \quad \beta-(N$-2-hydroxyethyl-DLaspartamide) (PHEA) and poly $[\alpha, \beta-(N-3-$ hydroxypropyl-DL-aspartamide)] (PHPA), were synthesized, characterized and screened for their antimalarial activity by Rajić et al. They found that polymeric conjugates, 75-77 showed better antimalarial activity than the glucosamine conjugate (64).

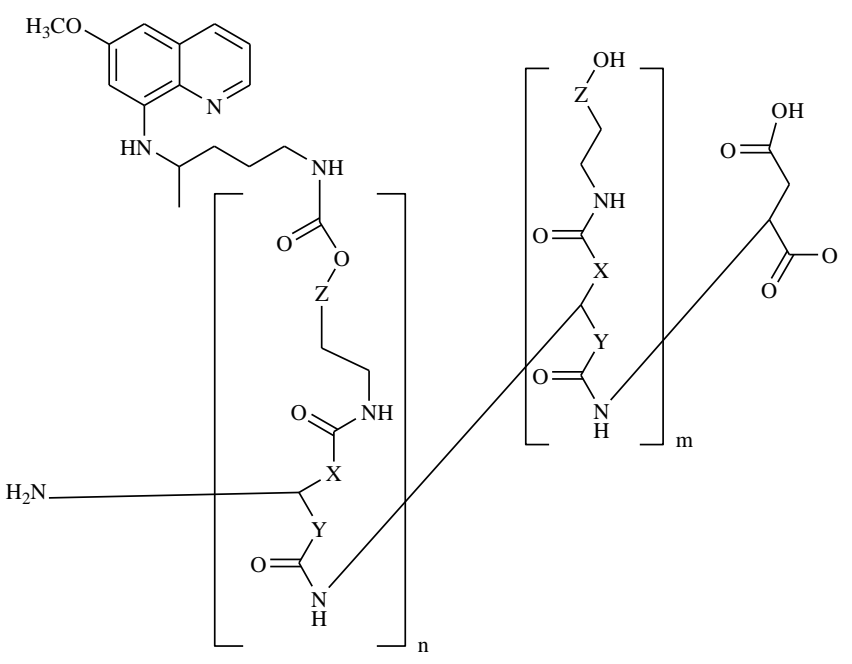

75: (PHEA-PQ) $\mathrm{Z}=0$

76: (PHEA-PQ) $Z=0$

77: (PHPA-PQ) $\mathrm{Z}=\mathrm{CH} 2$

$\alpha$ unit $\mathrm{X}=\mathrm{CH}_{2}, \mathrm{Y}=0, \beta$ unit $\mathrm{X}=0, \mathrm{Y}=\mathrm{CH}_{2}$

Various triclosan-conjugated analogs bearing biodegradable ester linkage were synthesized, characterized and evaluated for their antimalarial and antibacterial activities by Mishra et al. Dimethylaminoethyl-glutaryl esters of triclosan, $\mathbf{7 8}$ showed four-fold enhanced activities against $P$. falciparum and $E$. coli cultures than triclosan itself (65).<smiles>CN(C)CCOC(=O)CCCC(=O)Oc1cc(Cl)ccc1Oc1ccc(Cl)cc1Cl</smiles>

Chambel et al synthesized the imidazolidin-4ones, 79-89 as potential pro-prodrugs of the antimalarial primaquine. These compounds were designed with the aim of reducing the metabolic inactivation pathway of primaquine that involves oxidative deamination at the primary amino group. It also diminishes the blood toxicity induced by primaquine particularly its ability to provoke oxidation of oxyhemoglobin to methemoglobin. These compounds were found to be convincingly stable compounds, hydrolyzing to the consequent amino acid derivatives, 90 in $\mathrm{pH} 7.4$ buffer at $37^{\circ} \mathrm{C}$ with half-lives ranging from 9 to 30 days (66). 
<smiles>[M]C(CCCN1C(=O)[C@@H]([Z10])NC1([R])[R3])Nc1cc(OC)cc2cccnc12</smiles>

$\begin{array}{lll}\mathbf{R}_{1} & \mathbf{R}_{2} & \mathbf{R}_{3}\end{array}$

79: $\mathrm{H} \quad \mathrm{Me} \mathrm{Me}$

80: $\mathrm{CH}_{2} \mathrm{Ph} \mathrm{Me} \mathrm{Me}$

81: $\mathrm{CHMe}_{2} \mathrm{Me} \mathrm{Me}$

82: $\mathrm{H} \quad\left(\mathrm{CH}_{2}\right)_{4}$

83: $\mathrm{CH}_{2} \mathrm{Ph} \quad\left(\mathrm{CH}_{2}\right)_{4}$

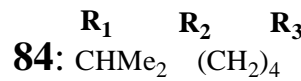

85: $\mathrm{H} \quad\left(\mathrm{CH}_{2}\right)_{5}$

86: $\mathrm{Me} \quad\left(\mathrm{CH}_{2}\right)_{5}$

87: $\mathrm{CH}_{2} \mathrm{Ph} \quad\left(\mathrm{CH}_{2}\right)_{5}$

88: $\mathrm{CHMe}_{2}\left(\mathrm{CH}_{2}\right)_{5}$

89: $\mathrm{H} \quad\left(\mathrm{CH}_{2}\right)_{6}$<smiles>[M]C(CCCNC(=O)C([R])N)Nc1cc(OC)cc2cccnc12</smiles>

90

Xie et al carried out therapeutic index evaluation and investigated pyrroloquinazolinediamine (PQD), 91, its prodrugs tetra-acetamide pyrroloquinazolinediamine (PQD-A4), 92 and bisethylcarbamyl pyrroloquinazolinediamine (PQD$\mathrm{BE}), 93$ for antimalarial activity. PQD-A4, PQD$\mathrm{BE}$, and $\mathrm{PQD}$ administered orally were found to be 20.0, 8.0, and 2.5 times safer than intravenously given artesunate (67).<smiles>Nc1nc(N)c2c(ccc3c2ccn3Cc2ccccc2C(F)(F)F)n1</smiles><smiles>CC(=O)N(C(C)=O)c1nc(N(C(C)=O)C(C)=O)c2c(ccc3c2ccn3Cc2ccccc2C(F)(F)F)n1</smiles>

92<smiles>CCOC(=O)Nc1nc(NC(=O)OCC)c2c(ccc3c2ccn3Cc2ccccc2C(F)(F)F)n1</smiles>

93

Vial et al synthesized neutral antimalarial prodrugs that deliver bisthiazolium compounds with antimalarial activity in the nanomolar range. These compounds were found to be suitable for both parenteral as well as oral use and plasma promotes rapid conversion of the prodrug into the parent drug. Oral administration of the TE3 prodrug, 94 was found to entirely cure Plasmodium cynomolgi infection in rhesus monkeys (68).

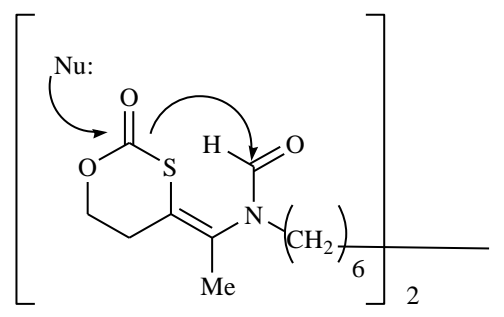

94

Vangapandu et al reported antimalarial activities of $\mathrm{N}^{8}$-(4-amino-1-methylbutyl)-5-alkoxy4-ethyl-6-methoxy-8-quinolinamines and their pro prodrug analogues synthesized by covalently connecting them to the redox-sensitive and esterase-sensitive linkers via the amide linkage. Synthesized analogues were evaluated for in vivo blood-schizontocidal activity as potential pro prodrug models for the primary amino group containing 8-quinolinamines. The most effective pro prodrug analogue, 95 displayed potential activities against drug-sensitive and drug-resistant strains of Plasmodia in vivo (69). 


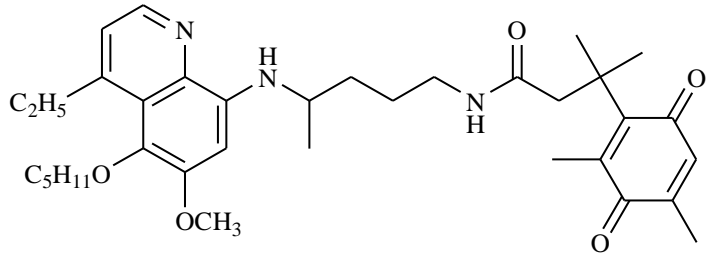

95

Ortmann et al developed acyloxyalkyl ester prodrugs of FR900098 with improved in vivo antimalarial activity. The most successful compound 96 demonstrated 2-fold increased activity in mice infected with the rodent malaria parasite Plasmodium vinckei (70).

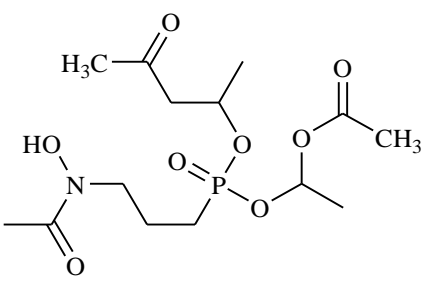

96

Reichenberg et al reported the synthesis of diaryl ester prodrugs of FR900098, 97 with improved in vivo antimalarial activity. The bis-(4methoxy phenyl) ester 98, was proved not only much efficient than FR900098 but proved to be equivalent to FR900098 administered by ip route (71).<smiles>CC(=O)N(O)CCCP(=O)(O)O</smiles>

97, FR900098<smiles>COc1ccc(OP(=O)(CCCN(O)C(C)=O)Oc2ccc(OC)cc2)cc1</smiles>

98

Prodrug form of a Plasmodium falciparum glutathione reductase inhibitor conjugated with a 4anilinoquinoline was identified by Davioud Charvet et al. They found that amino ester $\mathbf{9 9}$, was proved to be most active compound and equally effective against chloroquine sensitive and chloroquine resistant strains of Plasmodium falciparum (72).<smiles>CC(C)=C1C(=O)c2ccccc2C(=O)C1=C(C)C(=O)OCc1cc(NC(=O)CN2CCCCC2)cc(Nc2ccnc3cc(Cl)ccc23)c1</smiles>

99

Kinyanjui et al studied the reversal of activity against Plasmodium falciparum of WR99210 (4,6diamino-1,2-dihydro-2,2-dimethyl-1-[(2,4,5trichlorophenoxy)propyloxy]-1,3,5-triazine), a triazine antimalarial drug, and of the pro-drug PS15 by folic acid (FA) and folinic acid (FNA). They suggested that the action of PS-15 against $P$. falciparum was primarily due to a non-folate mechanism. PS-15, (N-(3-(2,4,5trichlorophenoxy)propyloxy)-N'-(1-methylethyl)imidocarbo-nimidodiamide hydrochloride), a close analog of proguanil, and a prodrug of WR99210 were developed to overcome the low bioavailability and gastrointestinal intolerance resulted from oral dosages of WR99210 in humans (73).

\section{Prodrugs of Antiviral Agents}

Viral infections are considered one of the principle threats to human life and health worldwide (74). Dong et al reported a new alkoxyalkylphosphodiester prodrug of ribavirin, designed to release the active ribavirinmonophosphate species selectively in nucleated cells while limiting its exposure in anucleated red blood cells (RBCs). Prodrug 100 was found to display enhanced in vitro antiviral activity against the hepatitis $\mathrm{C}$ virus replicon and influenza virus. These results indicated that synthesized prodrug was found to have the potential for safer, lower, less common and consistent administration than ribavirin (75). 
<smiles>CCOCCO[GeH2]OCCOP(=O)(O)OC1O[C@@H](n2cnc(C(N)=O)n2)[C@H](O)[C@H]1O</smiles>

100

Li et al described the synthesis of 6deoxycyclopropavir 101, a prodrug of cyclopropavir along with its in vitro and in vivo antiviral activity. It was found to exhibit little antiviral activity in culture but effective against murine cytomegalovirus infections in mice and against human cytomegalovirus infections in severe combined immunodeficient mice (76).

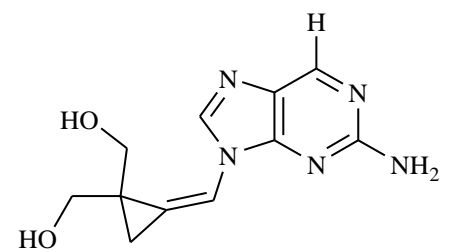

101

Hiramath et al synthesized and carried out in vitro and bioavailability studies of acyclovir prodrug. The macromolecular prodrug of acyclovir was synthesized by coupling the drug to PEG which was then polymerized to get polymeric prodrug, 102. The delayed release of free drug from the conjugate resulted in longer retention time in plasma and was found to have higher bioavailability of acyclovir from the PEG conjugate (77).

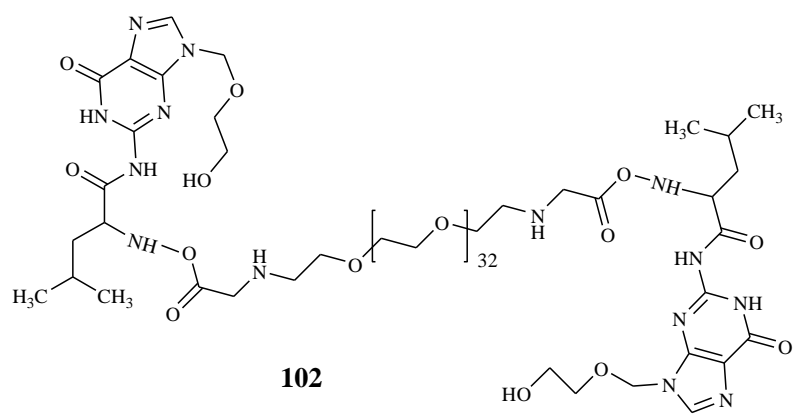

The affinity and permeability patterns of the amino acid ester prodrugs of acyclovir (ACV), 103 L-alanine-ACV, L-serine-ACV, L-serine-succinate$\mathrm{ACV}$ and L-cysteine-ACV were characterized by Katragadda et al on rabbit primary corneal epithelial cell culture as well as on rabbit cornea. In comparison to ACV, L-serine-ACV, 104 exhibited superior permeability across cornea along with excellent antiviral activity against herpes simplex virus and varicella-zoster virus (78).

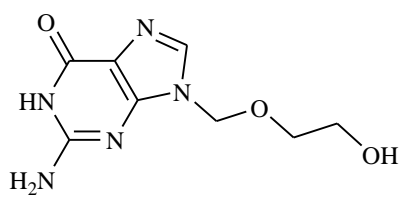

103<smiles>Nc1nc2c(ncn2COCCOC(=O)C(N)CO)c(=O)[nH]1</smiles>

104

$\mathrm{Wu}$ et al reported the synthesis of L-valine ester of cyclopropavir (valcyclopropavir) following the example of L-valine prodrugs of antiviral nucleosides analogues. Valcyclopropavir, 105 inhibited replication of human cytomegalovirus (HCMV, Towne and AD 169 strains) to approximately the same extent as the parent drug cyclopropavir, 106 and pharmacokinetic studies in mice indicated that the oral bioavailability of this prodrug was found to be $95 \%$ (79).<smiles>CC(C)C(N)C(=O)OCC1(CO)CC1=Cn1cnc2c(=O)[nH]c(N)nc21</smiles><smiles>Nc1nc2c(ncn2/C=C2\CC2(CO)CO)c(=O)[nH]1</smiles>

106

Shen et al synthesized 5'- $O$-D- and L-amino acid derivatives, 107-115 and $5^{\prime}-O-(\mathrm{D}-$ and Lamino acid methyl ester phosphoramidate), 116117, derivatives of vidarabine (ara-A). A number of 
compounds were found to be equi- or more potent in vitro against two pox viruses. These compounds exhibited improved uptake by cultured cells compared to the parent drug, 118 (80).<smiles>[R][C@H](N)C(=O)OC[C@H]1O[C@@H](n2cnc3c(N)ncnc32)[C@H](O)[C@@H]1O</smiles>

D-amino acid ester (a-g)<smiles>[R][C@H](N)C(=O)OC[C@H]1O[C@@H](n2cnc3c(N)ncnc32)[C@H](O)[C@@H]1O</smiles>

\section{L-amino acid ester (i-o)}

R:

107: a, i valine

108: $b, j$ leucine

109: $\mathrm{c}, \mathrm{k}$ isoleucine

110: d,i phenylalanine

111: e,m lysine

112: $\mathrm{f}, \mathrm{n}$ serine

113: g, o aspartic acid<smiles>Nc1ncnc2c1ncn2C1OC(COC(=O)C[C@H](N)C(=O)O)C(O)C1O</smiles>

114<smiles>Nc1ncnc2c1ncn2C1OC(COC(=O)C[C@H](N)C(=O)O)C(O)C1O</smiles>

115<smiles>[R]C([R])(NP(=O)(OCC1OC2OC1C(O)C2O)Oc1ccccc1)C(=O)OC</smiles>

116

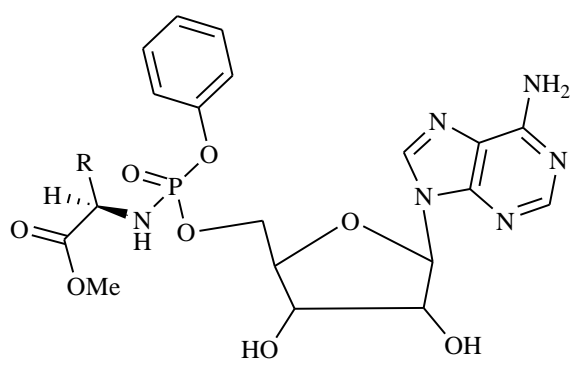

117<smiles>Nc1ncnc2c1ncn2C1OC(CO)C(O)C1O</smiles>

118

Tang et al synthesized a series of ester analogues of acyclic nucleotide adefovir and tenofovir as potent antiviral agents. The antiviral evaluation results indicated that bis benzyl ester prodrug of adefovir, 119 and bis allyl ester prodrug of tenofovir, 120 exhibited potent antiviral activities (81).

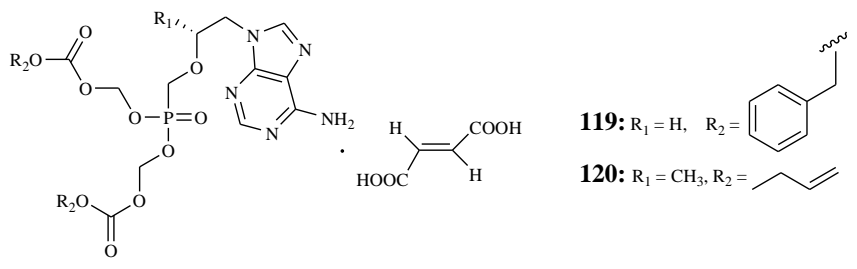

Meerbach et al presented a series of 42 lipophilic bromovinyldeoxyuridine monophosphates (BVDUMP) as potential prodrugs of the antiviral agent (E)-5-(2-bromovinyl)-2'deoxyuridine (BVDU). They applied 5'-cycloSal- 
masking group technique to this cyclic nucleoside analogue to accomplish delivery of the monophosphate of BVDU within the target cells. The triesters 3-methyl-cycloSal-3'-OH-BVDUMP 121, 5-H-cycloSal-3'-OH-BVDUMP 122, 5-Omethyl-cycloSal-3'-OH-BVDUMP $\quad \mathbf{1 2 3}, \quad 3,5-$ dimethyl-cycloSal-3'-OH-BVDUMP 124 and 6chloro-7-ethoxycarbonylmethylcycloSal-3'-OH-

BVDUMP 125 showed pronounced anti-Epstein Barr Virus effectiveness, which was found to be comparable with or even higher than that of acyclovir 103. Two derivatives 5-H-cycloSal-3'-Oacetyl- BVDUMP 126 and compound 124 had a slightly higher anti-varicella zoster virus activity than the parent compound BVDU 127 (82).

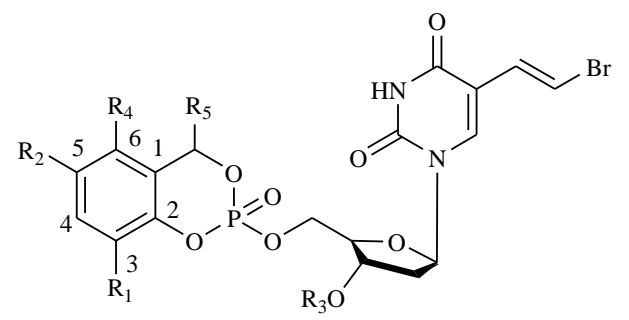

\begin{tabular}{llllll}
\hline & $\mathbf{R}_{\mathbf{1}}$ & $\mathbf{R}_{\mathbf{2}}$ & $\mathbf{R}_{\mathbf{3}}$ & $\mathbf{R}_{\mathbf{4}}$ & $\mathbf{R}_{\mathbf{5}}$ \\
\hline $\mathbf{1 2 1}$ & $\mathrm{CH}_{3}$ & $\mathrm{H}$ & $\mathrm{H}$ & $\mathrm{H}$ & $\mathrm{H}$ \\
$\mathbf{1 2 2}$ & $\mathrm{H}$ & $\mathrm{H}$ & $\mathrm{H}$ & $\mathrm{H}$ & $\mathrm{H}$ \\
$\mathbf{1 2 3}$ & $\mathrm{H}$ & $\mathrm{OCH}_{3}$ & $\mathrm{H}$ & $\mathrm{H}$ & $\mathrm{H}$ \\
$\mathbf{1 2 4}$ & $\mathrm{CH}_{3}$ & $\mathrm{CH}_{3}$ & $\mathrm{H}$ & $\mathrm{H}$ & $\mathrm{H}$ \\
$\mathbf{1 2 5}$ & $\mathrm{H}$ & $\mathrm{H}$ & $\mathrm{H}$ & $\mathrm{Cl}$ & Ethoxycarbonyl \\
& & & & & methyl \\
$\mathbf{1 2 6}$ & $\mathrm{H}$ & $\mathrm{H}$ & $\mathrm{COCH}_{3}$ & $\mathrm{H}$ & $\mathrm{H}$ \\
\hline
\end{tabular}<smiles>O=c1[nH]c(=O)n(C2CC(O)C(CO)O2)cc1/C=C/Br</smiles>

Song et al described the synthesis of amino acid ester prodrugs of the antiviral agent 2-bromo, 5-6 dichloro-1-( $\beta$-D-ribofuranosyl) benzimidazole and carried out evaluation of these compounds to check their efficiency as potential substrates of hPEPT1 transporter. These ester prodrugs, 128-139, were found to have 2-4 fold higher affinity for hPEPT1 compared to 2-bromo,5-6 dichloro-1-( $\beta$-Dribofuranosyl) benzimidazole (83).

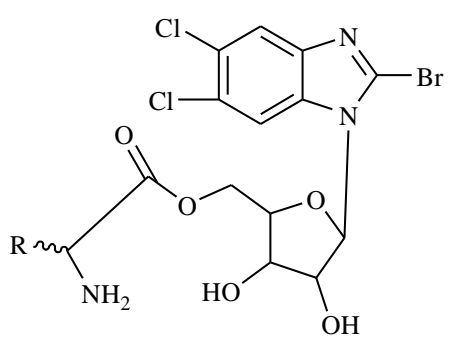

Where $\mathrm{R}=$
128: $\mathrm{L}-\mathrm{Val}-\mathrm{BDCRB}$
134: ${ }_{\mathrm{L}}$-Ile-BDCRB
129: $\mathrm{D}^{-}$Val-BDCRB
135: ${ }_{L}$-Phe-BDCRB
130: p-chloro-L-Phe-BDCRB
136: $\mathrm{D}^{-}$Phe-BDCRB
131: p-metoxy- L-Phe-BDCRB
137: p-ethoxy- L-
Phe-BDCRB
132: $\mathrm{L}^{-}$Pro-BDCRB
138: $\mathrm{L}$-Asp-BDCRB

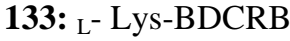
139: $\mathrm{D}^{-}$Asp-BDCRB

A dipeptide prodrug of the antiviral nucleoside acyclovir (ACV), val-val-ACV (VVACV), was developed and evaluated in vivo as a potential drug candidate for improving antiviral efficacy against herpetic epithelial and stromal keratitis by Anand et al. VVACV, the dipeptide prodrug of ACV, 103 was found to be highly soluble, stable in water, significantly less cytotoxic than parent drug and allowed formulation into $1 \%$ to $3 \%$ eye drops. In vivo, VVACV 140 exhibited excellent antiviral activity against epithelial and stromal keratitis in the rabbit eye model (84).<smiles>CC(C)C(N)C(=O)NC(C(=O)OCCOCn1cnc2c(=O)[nH]c(N)nc21)C(C)C</smiles>

140

Yang et al carried out chemical stability, enzymatic hydrolysis and nasal uptake studies of amino acid ester prodrugs of acyclovir. They found that the ${ }_{\text {-aspartate }} \beta$-ester prodrug, 141 could be absorbed nasally and was proved to be least labile to enzymatic hydrolysis in the nasal mucosa (85). 
<smiles>Nc1nc2c(ncn2COCCOC(=O)CC(N)C(=O)O)c(=O)[nH]1</smiles>

141

Potential oral prodrugs of the antiherpesvirus acyclonucleoside 9-[4-hydroxy-3-(hydroxymethyl)but1-yl]guanine (BRL 39123, 142) have been synthesized and evaluated for bioavailability in the blood of mice by Harnden et al. Oral bioavailability studies in healthy human subjects confirmed compound 143 as an effective prodrug (86).

Colla et al reported several water-soluble ester derivatives of acyclovir [9-[ (2hydroxyethoxy)methyl]guanine], i.e., the $2^{\prime}-O$ glycyl-, 2'- $O$ - $\alpha$-alanyl-, 2'- $O$ - $\beta$-alanyl- and 2'-O-3carboxypropionyl esters for their antiviral activity in cell culture. These four acyclovir esters 144-147 were proved to be almost as active as acyclovir, $\mathbf{1 0 3}$ and got readily hydrolyzed to release the parent compound (87).<smiles>Nc1nc2c(ncn2CCC(CO)CO)c(=O)[nH]1</smiles>

142, BRL 39123<smiles>CC(=O)OCC(CCn1cnc2cnc(N)nc21)COC(C)=O</smiles>

143<smiles>[R]OCCOCn1cnc2c(=O)[nH]c(N)nc21</smiles>

144: $\mathrm{R}=\mathrm{COCH}_{2} \mathrm{NH}_{2} \cdot \mathrm{HCl}$

145: $\mathrm{R}=\mathrm{COCH}\left(\mathrm{CH}_{3}\right) \mathrm{NH}_{2} \cdot \mathrm{HCl}$

146: $\mathrm{R}=\mathrm{COCH}_{2} \mathrm{CH}_{2} \mathrm{NH}_{2} \cdot \mathrm{HCl}$

147: $\mathrm{R}=\mathrm{COCH}_{2} \mathrm{CH}_{2} \mathrm{COONa}$
Acquired immunodeficiency syndrome (AIDS) is a degenerative disorder of the immune and central nervous system which is caused by human immunodeficiency virus (HIV). The HIV virus enters the CNS early in the course of the systemic infection, and any blockade in its progression leads to AIDS dementia and other neurological manifestations of HIV infection [88]. According to the statistical facts on the AIDS, outbreak of epidemic provided in 2013 by WHO, there were suspected cases of about 35 million people having HIV infection and 1.5 million deaths due to this disorder [89,90]. HIV acquires resistance to all presently accessible drugs, resulting in swiftly decreased drug effectiveness. There is incredible potential for improving anti-HIV therapy not only by increasing the potency of antiviral drugs, but also by reducing the burden of the dosing regimen. This can be achieved by modifying the physicochemical, biopharmaceutical and pharmacokinetic properties of drug through the development of prodrugs (91).

Agarwal HK et al synthesized three fatty acyl conjugates of emtricitabine as nucleoside prodrugs and evaluated these prodrugs against various strains of HIV-1. Due to improved lipophilicity and better cellular uptake the compound myristoylated conjugate of emtricitabine, $\mathbf{1 4 8}$ was proved to be a more effective analogue with a better resistance profile compared to its parent compound (92).

Guo et al designed and synthesized a series of ester prodrugs of 3-Hydroxymethyl-4-methyl- 3', 4'di-O-(S)-camphanoyl-(+)-cis-khellactone to explore the new drug candidates as non-nucleoside reverse transcriptase inhibitor. The ${ }_{\mathrm{L}}$-alanine ester prodrug

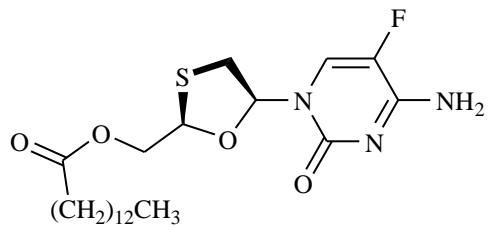

148

149 exhibited desirable pharmacokinetic properties in vitro and in vivo and showed improved oral bioavailability of $26 \%$ in rat, and would be a potential clinical candidate as a new anti-AIDS drug (93). 


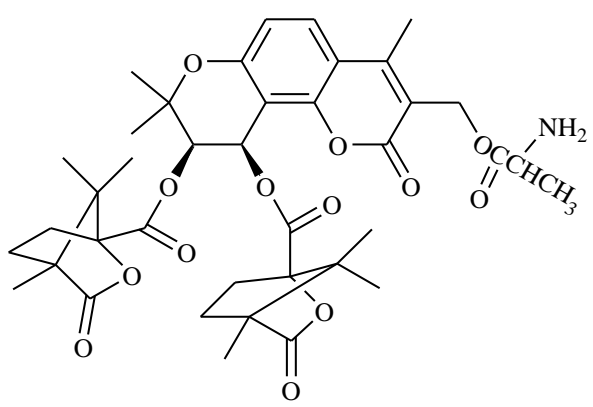

149

Phosphate and thiophosphate prodrugs 150,151 of anti-HIV agent azidothymidine were synthesized, and their anti-HIV activities as well as cytotoxicities were investigated in vitro by Qing-bin et al. The therapeutic index of $\mathbf{1 5 0}$ was found to be significantly higher than that of its parent drug azidothymidine, $\mathbf{1 5 2}$ and its thiophosphate counterpart 151 due to enhanced lipophilicity (94).

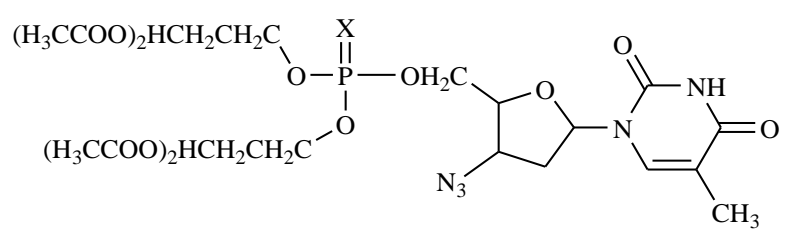

150: $\mathrm{X}=\mathrm{O}$,

151: $X=S$<smiles>Cc1cn(C2CC([N])C(CO)O2)c(=O)[nH]c1=O</smiles>

152

Agrawal et al designed and evaluated prodrug of zidovudine by coupling it to 2-hydroxymethyl methacrylate through a succinic spacer to get a monomeric drug conjugate which was polymerized to obtain the polymeric prodrug. Poly (HEMAzidovudine) conjugate, $\mathbf{1 5 3}$ was found to exhibit improved pharmacokinetics as compared to parent drug zidovudine, 154 by increasing its short life and bioavailability resulting in less frequent administration and decreased toxicity (95).

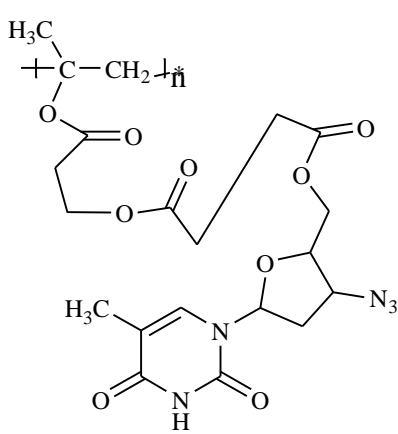

153<smiles>Cc1cn(C2CC([Al])C(CO)O2)c(=O)[nH]c1=O</smiles>

Li et al described the synthesis of S-acyl-2thioethyl (SATE) prodrug of 2' modified 5' noncarbocyclic adenine analogue and tested these prodrugs for antiviral activity. As the ionic character of a phosphonic acid presented an obstacle for cellular permeability, S-acyl-2thioethyl masked these charges with neutral groups to form more lipophilic derivatives capable of crossing the gastrointestinal wall and reverted back to the parent nucleoside phosphonic acid. SATE prodrug, 155 was found to exhibit 4 fold higher anti-HIV activity compared to parent compound (96).

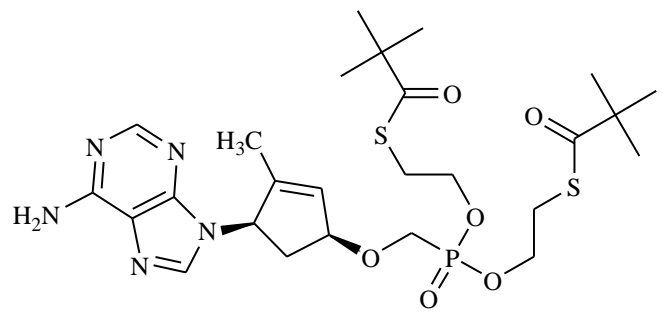

155

Yang et al synthesized a novel water-soluble chitosan- $O$-isopropyl-5'-O-stavudine monophosphate conjugate, 156. This resulting polymeric conjugate were evaluated in MT4 cell line and they were found to exhibit remarkable antiHIV effect and rather low cytotoxicity relative to parent nucleoside analogue owing to the effect of bypassing the rate-limiting step of monophosphorylation mediated by thymidine kinase. 
Nanoparticles of compound $\mathbf{1 5 6}$ were prepared by the process of ionotropic gelation using tripolyphosphate to augment the delivery to viral reservoirs of HIV. On comparing the data of chitosan- $O$-isopropyl-5'-O $O$-stavudine

monophosphate conjugate and stavudine-loaded nanoparticles, in vitro drug release studies revealed that the crosslinked conjugate nanoparticles can prevent the coupled drug from leaking out of the nanoparticles in blood circulation and provide a mild sustained release of stavudine 5 '-( $O$-isopropyl $)$ monophosphate without the burst release (97).

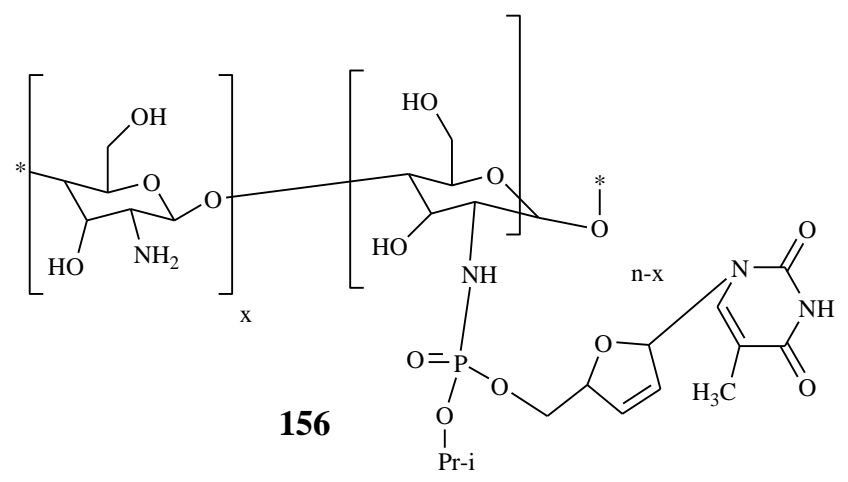

Liang et al synthesized a series of (-)- $\beta{ }^{-D^{-}}$ $(2 \mathrm{R}, 4 \mathrm{R})$-dioxolane-thymine-5'- $O$-aliphatic acid esters as well as amino acid esters as prodrugs of ()- $\beta-_{-}-(2 R, 4 R)$-dioxolane-thymine. These synthesized compounds were evaluated for antiHIV activity against HIV-1 $1_{\text {LAI }}$ in human peripheral blood mononuclear (PBM) cells and for their cytotoxicity in PBM, T-lymphoblastoid cell line obtained from American Type Culture Collection as well as African green monkey kidney cells. On comparing with the parent drug, the compounds 157-159, (5'- $O$-aliphatic acid esters) were found to be chemically stable and exhibited improved antiHIV potency in vitro without increase in cytotoxicity (98).<smiles>CC(=O)OCC1OCC(n2cc(C)c(=O)[nH]c2=O)O1</smiles>

157: $\mathbf{R}=\mathrm{C}_{4} \mathrm{H}_{9}$

158: $\mathbf{R}=\mathrm{C}_{7} \mathrm{H}_{15}$

159: $\mathbf{R}=\mathrm{C}_{11} \mathrm{H}_{23}$

To improve the pharmacological properties as well as pharmacokinetic profiles of the current protease inhibitors (PIs) and consequently therapeutic potential, Roche et al reported the synthesis of PI-spacer-valine prodrugs (PIsaquinavir, indinavir and nelfinavir). They evaluated these synthesized prodrugs for in vitro stability with respect to hydrolysis, anti-HIV activity, cytotoxicity and permeation through a monolayer of Caco-2 cells as compared with their parent PIs and first generation of valine-PIs. They found that PI-spacer-valine prodrugs, 160-164 proved to be chemically more stable than the first generation PI-Val prodrugs with respect to hydrolysis (99).<smiles>CC(C)(C)NC(=O)[C@@H]1CC2CCCCC2CN1C[C@H](Cc1ccccc1)NC(=O)[C@H](CC(N)=O)NC(=O)c1ccc2ccccc2n1</smiles>

160:Saq-C(O)C5NVal, $\mathrm{R}_{\mathrm{a}}=\mathrm{ValNH}\left(\mathrm{CH}_{2}\right)_{5} \mathrm{C}(\mathrm{O})$,<smiles>CO[C@@H]1Cc2ccccc2[C@@H]1NC(=O)[C@@H](Cc1ccccc1)CC(CN1CCN(Cc2cccnc2)C[C@H]1C(=O)NC(C)(C)C)O[Na]</smiles>

161:Ind(8)-C(O)C5NVal, $\mathrm{R}_{\mathrm{a}}=\mathrm{H}$, $\mathrm{R}_{\mathrm{b}}=\operatorname{ValNH}\left(\mathrm{CH}_{2}\right)_{5} \mathrm{CO}$

162: Ind $[\mathrm{C}(\mathrm{O}) \mathrm{C} 5 \mathrm{NVal})] 2, \mathrm{R}_{\mathrm{a}}=\mathrm{R}_{\mathrm{b}}=\operatorname{ValNH}\left(\mathrm{CH}_{2}\right)_{5} \mathrm{CO}$<smiles>Cc1c(OC(=O)[O-])cccc1C(=O)N[C@H](CSc1ccccc1)[C@H](O)CN1CC2CCCCC2C[C@H]1C(=O)NC(C)(C)C</smiles>

163: Nelf(1)-(C)OC5NVal, $R_{a}=H, R_{b}=$ ValNH $\left(\mathrm{CH}_{2}\right)_{5} \mathrm{CO}$

164: Nelf- $[\mathrm{C}(\mathrm{O}) \mathrm{C} 5 \mathrm{NVal}] 2$ (2TFA), $\mathrm{R}_{\mathrm{a}}=\mathrm{R}_{b}=$ ValNH $\left(\mathrm{CH}_{2}\right)_{5} \mathrm{CO}$ 
Prodrugs of $(-)-\beta-_{-}-(2 R, 4 R)-1,3$-dioxolane2,6-diamino purine (DAPD), amdoxovir, organic salts of DAPD, 5'- - $^{-v a l y l}$ DAPD and $N-1$ substituted $\quad(-)-\beta-_{-}-(2 R, 4 R)-1,3$-dioxolane guanosine (DXG) have been synthesized and evaluated for anti-HIV activity against HIV-1 $1_{\text {LAI }}$ in primary human lymphocytes by Narayanasamy et al. $\quad(-)-\beta-_{-}-(2 R, 4 R)-1,3$-dioxolane-2-amino-6aminoethyl purine, $\mathbf{1 6 5}$ was found to be 17 times more potent than that of DAPD. 5'-L-Valyl DAPD, 166 and organic acid salts, 167-170 also indicated enhanced anti-HIV activity in comparison to DAPD due to improved water solubility, while DXG prodrugs exhibited lower potency than that of DXG or DAPD (100).<smiles>CCNc1nc(N)nc2c1ncn2[C@@H]1CO[C@@H](CO)O1</smiles>

165<smiles>CC(C)C(N)C(=O)OC[C@H]1OC[C@H](n2cnc3c(N)nc(N)nc32)O1</smiles>

166<smiles>[R]n1c(N)nc2c(ncn2[C@H]2CO[C@@H](CO)O2)c1=O</smiles>

167: DAPD maleate mono salt

169: DAPD citrate hemi salt

168: DAPD tartarate hemi salt

170: DAPD fumarate hemi salt

Sriram et al described the synthesis of a new series of abacavir prodrugs with improved lipophilicity. The in vitro anti-HIV activities indicated that compound (3-(2-(4-methylaminobenzylideneamino)-6-(cyclopropylamino)-9Hpurin-9-yl) cyclopentyl)methanol 171, proved to be most potent compound with $\mathrm{EC}_{50}$ (effective concentration of compound (IM) achieving 50\% protection in MT-4 cell lines against the cytopathic effect of HIV-1) of $0.05 \mu \mathrm{M}$ and $\mathrm{CC}_{50}$ (cytotoxic concentration of compound (lM) required to reduce the viability of mock infected American Type Culture Collection cells by $50 \%$ ), of $>100 \mu \mathrm{M}$ with selectivity index of >2000 (101).<smiles>Cc1ccc(/C=N/c2nc(NC3CC3)c3ncn(C4C=CC(CO)C4)c3n2)cc1</smiles>

Mills et al synthesized and evaluated novel prodrugs of foscarnet and dideoxycytidine, 172-176 with a universal carrier compound comprising a chemiluminescent and a photochromic conjugate to enhance their cellular uptake. An increase of about 5 times in the activity of prodrugs of foscarnet as well as dideoxycytidine was observed in cultured macrophages infected with HIV and in mice infected with the retrovirus Friend leukemia virus than the parent drug (101).<smiles>[R]c1ccc(C(=C/C=C/C(Nc2ccn(C3CCC(CO)O3)c(=O)n2)(c2ccc([R])cc2)c2ccc(N(CC)c3ccc4c(=O)[nH][nH]c(=O)c4c3)cc2)c2ccc(N(CC)c3ccc4c(=O)[nH][nH]c(=O)c4c3)cc2)cc1</smiles>

172: $\mathrm{R}=\mathrm{N}\left(\mathrm{CH}_{3}\right)_{2}$

173: $\mathrm{R}=\mathrm{H}$ 
<smiles>[M]OP(=O)(OC(C=CC=C(c1ccc([R])cc1)c1ccc(N(CC)c2ccc3c(=O)[nH][nH]c(=O)c3c2)cc1)(c1ccc([R])cc1)c1ccc(N(CC)c2ccc3c(=O)[nH][nH]c(=O)c3c2)cc1)C(=O)OC</smiles>

174: $\mathrm{R}=\mathrm{N}\left(\mathrm{CH}_{3}\right)_{2}$

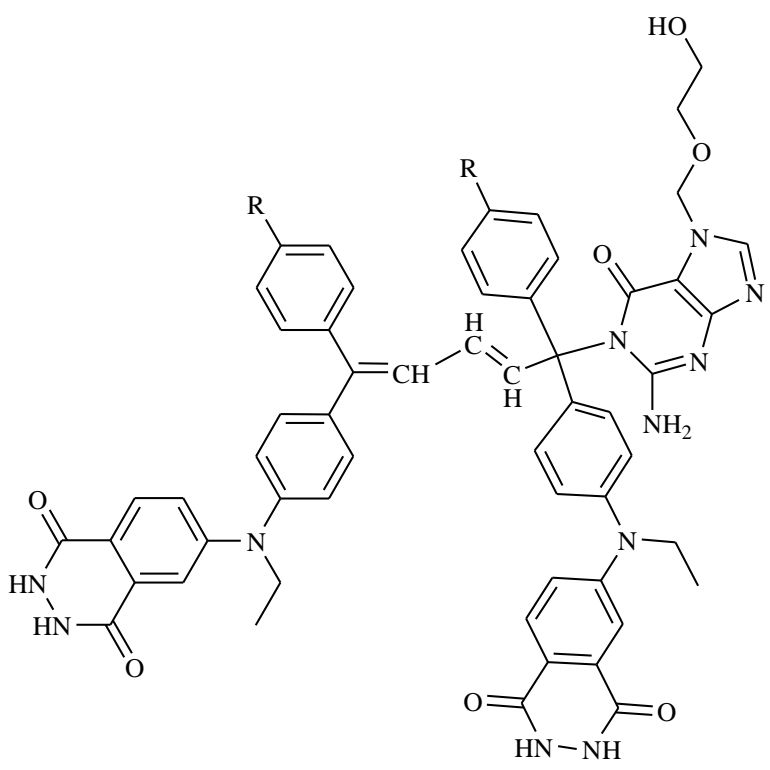

175: $\mathrm{R}=\mathrm{N}\left(\mathrm{CH}_{3}\right)_{2}$

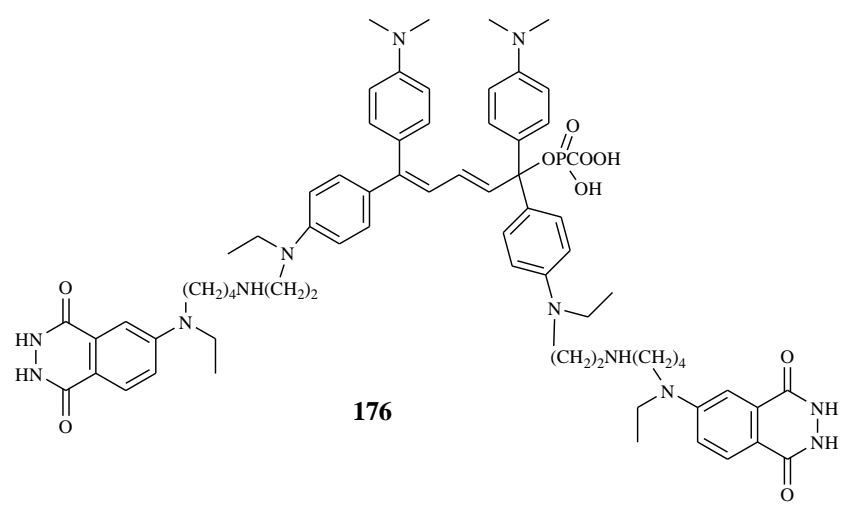

Hamada et al designed and synthesized water-soluble prodrugs of KNI-727, 177 a potent small-sized dipeptide-type HIV-1 protease inhibitor consisting of an Apns-Dmt core (Apns; allophenylnorstatine, Dmt; (R)- 5,5-dimethyl-1,3thiazolidine-4-carboxylic acid) as inhibitory machinery and carried out its kinetic studies. The synthetic prodrug, $\mathbf{1 7 8}$ was found to exhibit improved water-solubility $(13 \mathrm{mg} / \mathrm{mL})$ more than 8000-fold in comparison with the parent compound, 177 resulted in improved oral absorption and bioavailability (102).

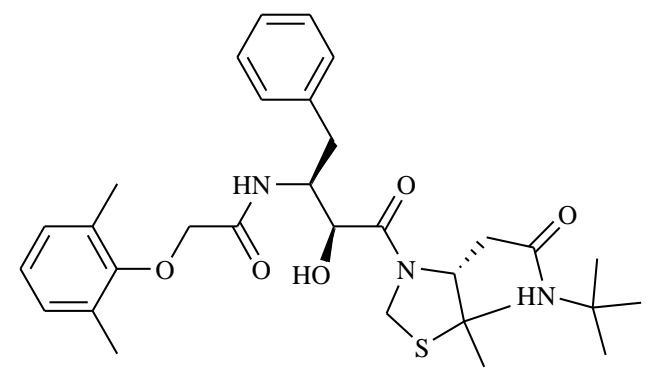

177<smiles>CC(C)=CC(=O)[C@H]1N(C(=O)[C@@H](OC(=O)COc2c(C)cccc2C)[C@H](Cc2ccccc2)NC(C)(C)C)CSC1(C)C</smiles>

178

Miazga et al presented the novel synthesis of 2',3'-dideoxy-3' fluoro-2-thiothymidine ( ${ }^{2}$ FLT) based on transformation of appropriately protected $1-\beta$-D-threo-ribofuranosylthymine. $\mathbf{1 7 9}$ and $\mathbf{1 8 0}$ were found to be most potent inhibitors of HIV-1 and exhibited ten times higher anti-HIV-1 activity and higher therapeutic index than their mother nucleoside $S^{2}$ FLT (103).

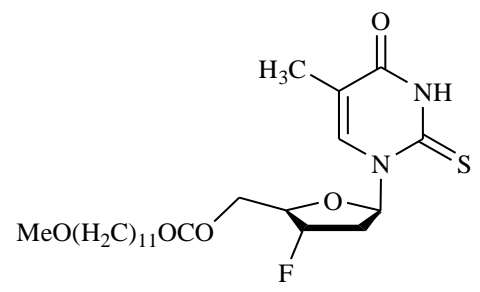

179 


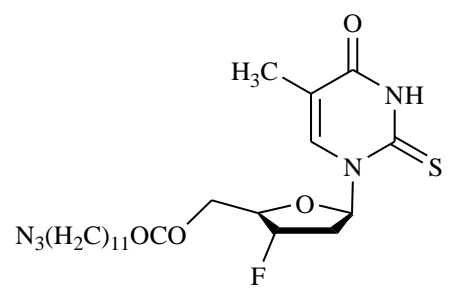

180

To modify the transport of the HIV protease inhibitors across the intestinal and blood brain barriers and their penetration into the central nervous system, the development of different acyl and carbamatoyl glucose-containing prodrugs derived from saquinavir, indinavir and nelfinavir have been carried out by Rouquayrol et al. They also evaluated these compounds for in vitro stability with respect to hydrolysis and anti-HIV activity. These glucose-linked ester and carbamate prodrugs 181-189 were found to display a promising therapeutic potential (104).<smiles>CC(C)(C)NC(=O)C1CC2CCCCC2CN1C[C@H](Cc1ccccc1)N[C@@H](O)CC(NC(=O)c1ccc2ccccc2n1)C(N)=O</smiles>

Saquinavir $\left(\mathrm{R}_{\mathrm{a}}=\mathrm{H}\right)$

181: $\mathrm{R}_{\mathrm{a}}=\mathrm{C}(\mathrm{O})\left(\mathrm{CH}_{2}\right)_{2} \mathrm{C}(\mathrm{O})-\mathrm{Glc}$

182: $\mathrm{R}_{\mathrm{a}}=\mathrm{C}(\mathrm{O}) \mathrm{CH}_{2}-\mathrm{Glc}$

183: $\mathrm{R}_{\mathrm{a}}=\mathrm{C}(\mathrm{O})\left(\mathrm{CH}_{2}\right)_{4} \mathrm{Glc}$

184: $\mathrm{R}_{\mathrm{a}}=\mathrm{C}(\mathrm{O}) \mathrm{NH}\left(\mathrm{CH}_{2}\right)_{4}-\mathrm{Glc}$<smiles>COC(CC(Cc1ccccc1)C(=O)N[C@H]1c2ccccc2C[C@H]1O)CN1CCN(Cc2cccnc2)C[C@H]1C(=O)NC(C)(C)C</smiles>

Indinavir $\left(\mathrm{R}_{\mathrm{a}}=\mathrm{R}_{\mathrm{b}}=\mathrm{H}\right)$

185: $\mathrm{R}_{\mathrm{a}=\mathrm{H}}, \mathrm{R}_{\mathrm{b}}=\mathrm{C}(\mathrm{O})\left(\mathrm{CH}_{2}\right)_{2} \mathrm{C}(\mathrm{O})-\mathrm{Glc}$

186: $\mathrm{R}_{\mathrm{a}}=\mathrm{H}, \mathrm{R}_{\mathrm{b}}=\mathrm{C}(\mathrm{O})\left(\mathrm{CH}_{2}\right)_{4}-\mathrm{Glc}$

187: $\mathrm{R}_{\mathrm{a}}=\mathrm{C}(\mathrm{O}) \mathrm{NH}\left(\mathrm{CH}_{2}\right)_{4}-\mathrm{Glc}, \mathrm{R}_{\mathrm{b}}=\mathrm{H}$<smiles>[R6]Oc1cccc(C(=O)N[C@H](CSc2ccccc2)[C@H]([O+])CN2CC3CCCCC3C[C@H]2C(=O)NC(C)(C)C)c1C</smiles>

Nelfinavir $\left(\mathrm{R}_{\mathrm{a}}=\mathrm{R}_{\mathrm{b}}=\mathrm{H}\right)$

188: $\mathrm{R}_{\mathrm{a}}=\mathrm{H}, \mathrm{R}_{\mathrm{b}}=\mathrm{C}(\mathrm{O})\left(\mathrm{CH}_{2}\right)_{2} \mathrm{C}(\mathrm{O})-\mathrm{Glc}$

189: $\mathrm{R}_{\mathrm{a}}=\mathrm{C}(\mathrm{O}) \mathrm{NH}\left(\mathrm{CH}_{2}\right)_{4}-\mathrm{Glc}, \mathrm{R}_{\mathrm{b}}=\mathrm{H}$

Matsumoto et al designed and synthesized conjugates of HIV protease inhibitors with nucleoside reverse transcriptase inhibitors based on the prodrug concept as well as the combination of two classes of anti HIV agents. The low antiviral activities of these inhibitors were probably due to their inadequate cell membrane permeability caused by the presence of free carboxylic acid in the inhibitors. Direct esterification of carboxyl group of the HIV protease inhibitors with 5'-hydroxyl group of the nucleoside reverse transcriptase inhibitor provided remarkably potent anti-HIV agents. 190 and 191 conjugates exhibited excellent antiviral activity compared with that of individual inhibitors (105).

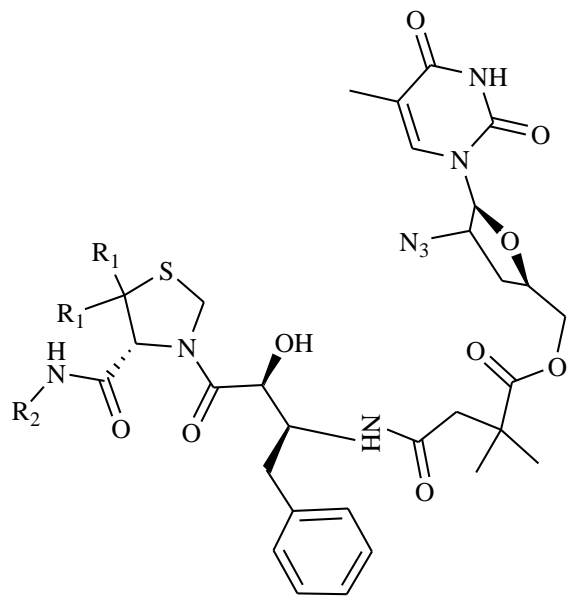

190: $\left(\mathrm{R}_{1}=\mathrm{Me}, \mathrm{R}_{2}=\right.$ tert-butyl)

191: $\left(R_{1}=\right.$ Me, $R_{2}=2$-methylbenzyl $)$

Farèse-Di Giorgio et al synthesized and investigated anti HIV activity as well as 
cytotoxicity of prodrugs derived from saquinavir and indinavir, 192-199. Ind-Oleyl, 196 displayed both a high inhibitory level and high chemical stability. No cytotoxicity was detected for these synthesized prodrugs for concentration as high as 10 or even $100 \mu \mathrm{M}$ (106).<smiles>[R7]OC(CN1CC2CCCCC2C[C@H]1C(=O)NC(C)(C)C)[C@H](Cc1ccccc1)NC(=O)[C@H](CC(N)=O)NC(=O)c1ccc2ccccc2n1</smiles>

192:Saq-Oleyl, $\mathrm{R}=\mathrm{CO}\left(\mathrm{CH}_{2}\right)_{7} \mathrm{CH}=\mathrm{CH}\left(\mathrm{CH}_{2}\right)_{7} \mathrm{CH}_{3}$ 193: Saq-Myr, $\mathrm{R}=\mathrm{CO}\left(\mathrm{CH}_{2}\right)_{12} \mathrm{CH}_{3}$ 194:Saq PEG350, $\mathrm{R}=\mathrm{COC}_{2} \mathrm{H}_{4} \mathrm{CO}\left(\mathrm{OC}_{2} \mathrm{H}_{4}\right)_{7} \mathrm{OCH}_{3}$ 195:Saq PEG2000, $\mathrm{R}=\mathrm{COC}_{2} \mathrm{H}_{4} \mathrm{CO}\left(\mathrm{OC}_{2} \mathrm{H}_{4}\right)_{44} \mathrm{H}_{3}$<smiles>[R6]O[C@@H]1Cc2ccccc2[C@@H]1NC(=O)[C@H](Cc1ccccc1)CC(CCCC)CN1CCN(Cc2cccnc2)C[C@H]1C(=O)NC(C)(C)C</smiles>

196: Ind-Oleyl, $\mathrm{R}_{\mathrm{a}}=\mathrm{H}, \mathrm{R}_{\mathrm{b}}=\mathrm{CO}\left(\mathrm{CH}_{2}\right)_{7} \mathrm{CH}=\mathrm{CH}\left(\mathrm{CH}_{2}\right)_{7} \mathrm{CH}_{3}$ 197: Ind-Myr, $\mathrm{R}_{\mathrm{a}}=\mathrm{H}, \mathrm{R}_{\mathrm{b}}=\mathrm{CO}\left(\mathrm{CH}_{2}\right)_{12} \mathrm{CH}_{3}$ 198: Ind-PEG350, $\mathrm{R}_{\mathrm{a}=} \mathrm{R}_{\mathrm{b}}=\mathrm{COC}_{2} \mathrm{H}_{4} \mathrm{CO}\left(\mathrm{OC}_{2} \mathrm{H}_{4}\right)_{7} \mathrm{OCH}_{3}$ 199: Ind-PEG2000, $\mathrm{R}_{\mathrm{a}}=\mathrm{H}, \mathrm{R}_{\mathrm{b}=} \mathrm{COC}_{2} \mathrm{H}_{4} \mathrm{CO}\left(\mathrm{OC}_{2} \mathrm{H}_{4}\right)_{44} \mathrm{OCH}_{3}$

Machado et al studied antiviral activity and resistance profile of phosphazid, a novel prodrug of zidovudine. This prodrug was found to have a higher selective index than the parent drug (107).

\section{Prodrugs of Antifungal Agents}

Fungal pathogens are a major public health threat with significant global effects which, surprisingly, are not being addressed as they should. These pathogens are widely distributed in soil, plant debris and other organic substrates (108). Fungal infections are caused by these microscopic organisms that can invade the epithelial tissue. Especially in the developed countries fungal infections have grown rapidly in last few decades and proved to be a significant cause of morbidity and mortality despite advances in medicinal chemistry. For the treatment of opportunistic fungal infections, the development of new potent or structural modification of the already available antifungal drugs is an important challenging task for modern medicine, with a potent, broad spectrum of antifungal activity, good pharmacokinetics and excellent bioavailability.

A number of prodrugs have been synthesized to combat the severity of fungal infections. Few of them are mentioned here. To improve the aqueous solubility of an itraconazole analogue YL-24, 200, Liu et al synthesized a series of novel prodrugs and carried out its in vivo antifungal activity. The phosphate disodium salt compound 201, among these prodrugs, exhibited excellent aqueous solubility $(9.8 \mathrm{mg} / \mathrm{mL})$ at near-neutral $\mathrm{pH}$, adequate stability in buffer solutions, as well as complimentary pharmacokinetic profiles (107).
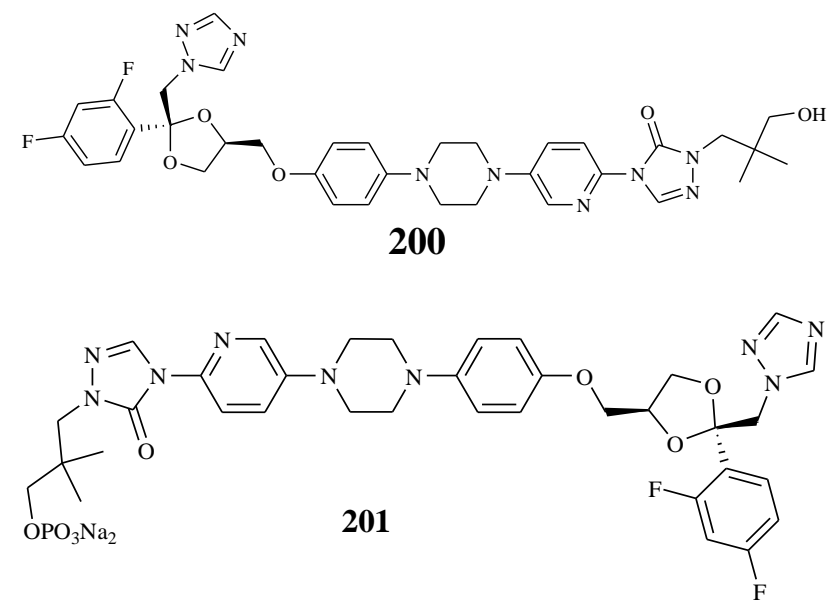

Kagoshima et al described the synthesis and evaluation of a number of novel water soluble ester prodrugs of antifungal triazole CS-758. Compound 202 was found to have good water solubility (>30 $\mathrm{mg} / \mathrm{mL}$ ), consequently proved to be a promising antifungal agent for parenteral use (108).

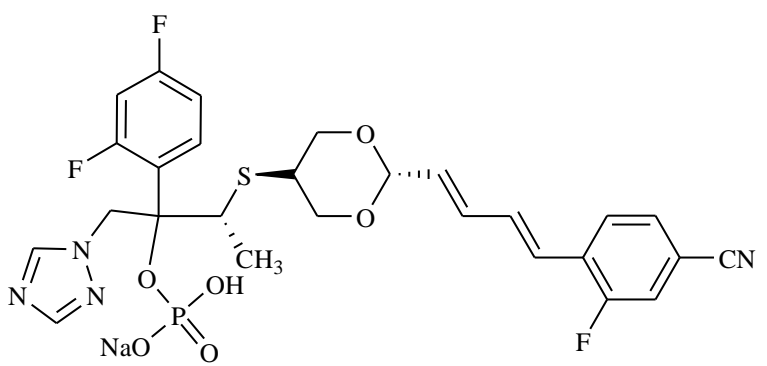

202 
Synthesis of phosphonooxymethyl derivatives of ravuconazole, 2 (BMS-379224) and 3 (BMS$315801)$ and their biological evaluation as potential water-soluble prodrugs was described by Ueda et al. Both derivatives exhibited high solubility in water and transformed to the parent compound in presence of alkaline phosphatase, as well as in vivo. BMS-379224, 203 has proved to be one of the most promising prodrug and has now advanced to its clinical study as an intravenous formulation of parent compound, ravuconazole 204 (109).

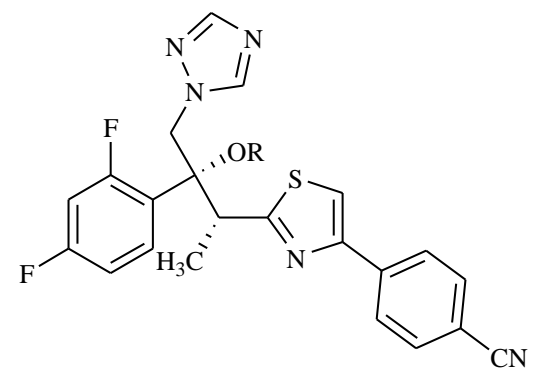

203: $\mathrm{BMS} 379224, \mathrm{R}=-\mathrm{CH}_{2} \mathrm{OP}(\mathrm{O})(\mathrm{OH})_{2}$

204: Ravuconazole, $\mathrm{R}=\mathrm{H}$,

Design, synthesis and antifungal activity of a novel water soluble prodrug, RO0098557, 205 of antifungal triazole was carried out by Ohwada et al. This synthesized prodrug was found to exhibit high chemical stability and water solubility along with strong antifungal activity against systemic candidiasis and aspergillosis (110).

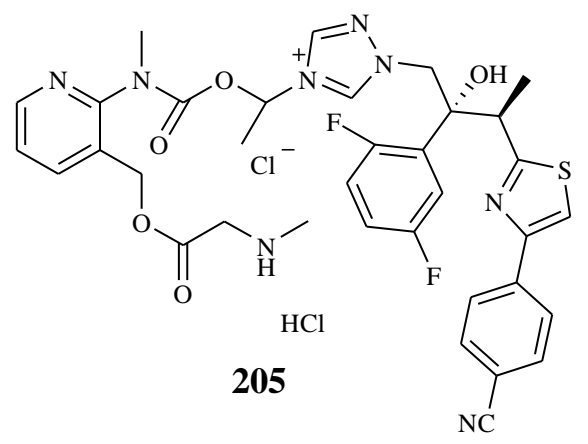

In previous study Ohwada et al synthesized water soluble N-benzyltriazolium or $\mathrm{N}$ benzylimidazolium salt type prodrugs of many highly lipophilic triazole or imidazole antifungals. The prodrug 206 was found to have sufficient chemical stability as well as water solubility for parenteral use. It showed rapid and quantitative transformation to the active substance in human plasma (111).<smiles>CNCC(=O)Oc1c(C)cc(C[n+]2cnn(C[C@](O)(c3ccc(F)cc3F)[C@@H](C)c3nc(-c4ccc(C#N)cc4)cs3)c2)cc1C</smiles>

206

Sun et al carried out synthesis and evaluation of various $\mathrm{N}$-acyloxymethylcarbamate linked prodrugs of 3-amido pseudomycin analogues. These synthesized combinations, 207-210 demonstrated improved toxicity profiles in comparison to their corresponding 3-amides as well as the parent pseudomycin B. They were found to exhibit good in vivo efficacy against murine candidiasis (112).

In another study Sun et al described the synthesis, bioconversion, antifungal activity, in addition to preliminary toxicology evaluation of a series of $\mathrm{N}$-acyloxymethyl carbamate linked triprodrugs of pseudomycins. Two pseudomycin triprodrugs 211, 212 showed excellent in vivo efficacy against systemic candidiasis (113).

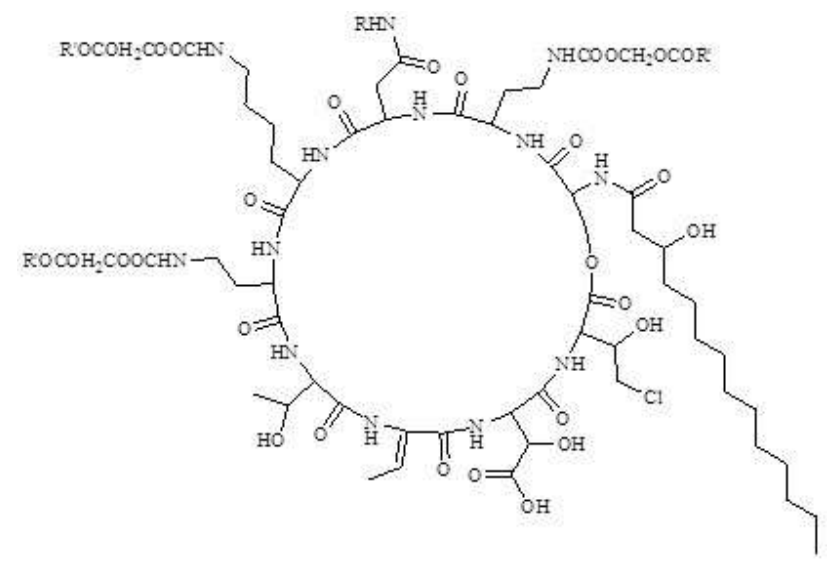

207: $\mathrm{R}=\mathrm{c}-\mathrm{Pr}, \mathrm{R}^{\prime}=\mathrm{i}-\mathrm{Pr}$

208: $\mathrm{R}=\mathrm{CH}_{2} \mathrm{CH}_{2} \mathrm{NMe}_{2}, \mathrm{R}^{\prime}=\mathrm{i}-\mathrm{Pr}$

209: $\mathrm{R}=$ GlyOMe, $\mathrm{R}^{\prime}=\mathrm{i}-\mathrm{Pr}$

210: $R=$ GlyOMe, $R^{\prime}=t-B u$ 


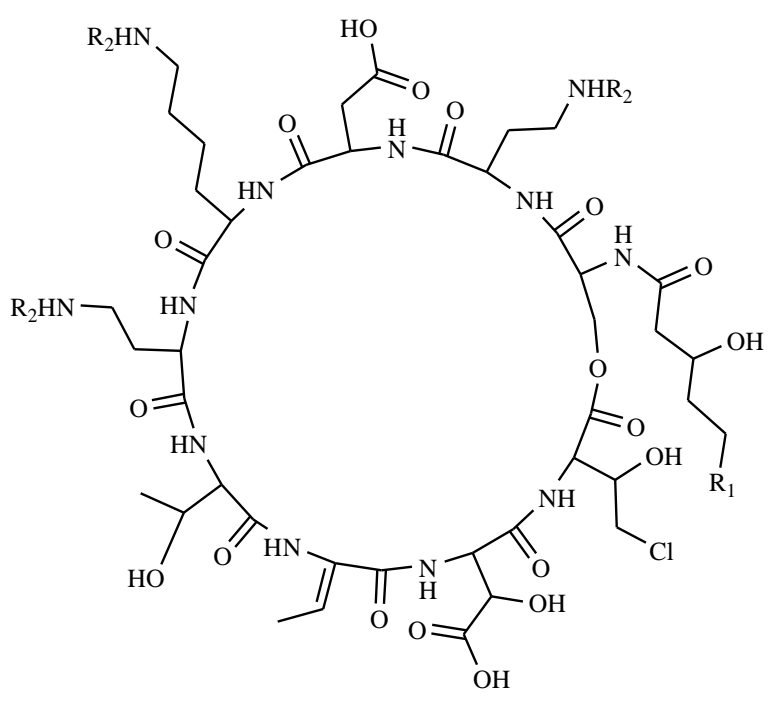

211: $\mathrm{R}_{1}=\mathrm{C}_{9} \mathrm{H}_{19-\mathrm{n}}, \mathrm{R}_{2}=-\mathrm{C}(\mathrm{O}) \mathrm{OCH}_{2} \mathrm{OC}(\mathrm{O}) \mathrm{Bu}-\mathrm{t}$

212: $\mathrm{R}_{1}=\mathrm{C}_{11} \mathrm{H}_{23-\mathrm{n}}, \mathrm{R}_{2}=-\mathrm{C}(\mathrm{O}) \mathrm{OCH}_{2} \mathrm{OC}(\mathrm{O}) \mathrm{Bu}-\mathrm{t}$

Rodriguez et al reported synthesis of phosphonate and phosphate esters prodrugs on the phenolic hydroxy of two echinocandin semisynthetic derivatives. Phosphate analogs have been developed in order to improve the water solubility properties of this important class of antifungal compounds. The phosphate prodrug, 213 possessed enhanced water solubility (>12 $\mathrm{mg} / \mathrm{mL}$ ) relative to parent drug, $214(<0.1 \mathrm{mg} / \mathrm{mL})(114)$.

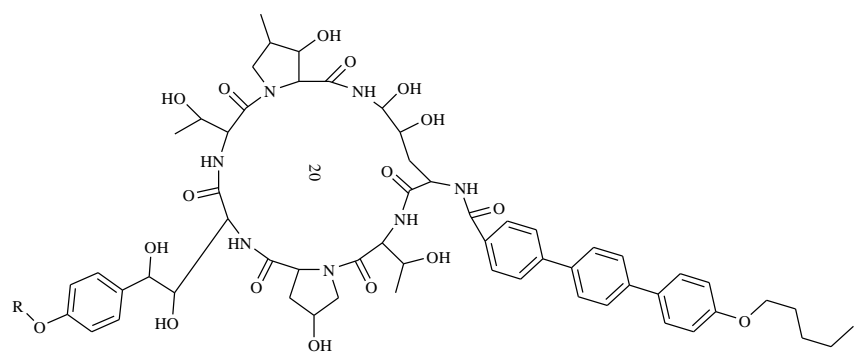

213: $\mathrm{R}=\mathrm{P}(\mathrm{O})(\mathrm{OH})_{2}$

214: $\mathrm{R}=\mathrm{H}$

\section{RECENT PATENTS}

Over the past few decades, number of patents has been issued in the field of anti-infective agents encompassing a range of drugs having various activities. The patents described in Table 2 reveal information related to various features, salient approaches and advancements of antiinfective agents.

\section{FUTURE PROSPECTS}

Prodrugs of antiinfective agents can present an attractive option to improve undesirable properties of a wide variety of these drugs without losing the benefits of the parent drug molecule. Nonetheless, developing a prodrug of these available antimicrobial agents can still be more feasible, economical and faster strategy than searching for an entirely new therapeutically active agent with suitable ADME (absorption, distribution, metabolism and excretion) properties. Hence, antiinfective prodrugs are becoming an essential element of drug discovery paradigm, as illustrated by the increasing number of its approved prodrugs and patents. Moreover, the development of novel and highly efficacious antimicrobial prodrugs and their preface in clinical therapy would be much fruitful in forthcoming years.

\section{CONFLICT OF INTEREST}

The authors have declared no conflict of interest.

\section{ACKNOWLEDGMENTS}

Indian Council of Medical Research, New Delhi, India, is duly acknowledged for awarding SRF to Ms. Mona Piplani vide Letter no. 45/07/2013/PHA/BMS. 
Table 2. List of patents related to antiinfective prodrugs

\begin{tabular}{|c|c|c|c|c|}
\hline S. No. & Publication date & Patent number & Invention disclosed & Reference \\
\hline 1. & $26 / 09 / 2013$ & US0253196A1 & $\begin{array}{l}\text { Salts of prodrugs of piperazine and } \\
\text { substituted piperidine antiviral agents }\end{array}$ & (115) \\
\hline 2. & $13 / 06 / 2013$ & WO084214A2 & $\begin{array}{l}\text { Pyrazinoic acid prodrugs activated by } \\
\text { esterases of mycobacteria }\end{array}$ & $(116)$ \\
\hline 3. & $27 / 12 / 2012$ & WO177986A2 & $\begin{array}{l}\text { Conjugate-based antifungal and } \\
\text { antibacterial prodrugs }\end{array}$ & $(117)$ \\
\hline 4. & $20 / 12 / 2012$ & WO174121A2 & Decoquinate prodrugs & $(118)$ \\
\hline 5. & $15 / 12 / 2011$ & WO156674A2 & $\begin{array}{l}\text { Thioether prodrug compositions as anti-hiv } \\
\text { and anti-retroviral agents }\end{array}$ & $(119)$ \\
\hline 6. & $25 / 10 / 2011$ & US $8044230 \mathrm{~B} 2$ & $\begin{array}{l}\text { Water soluble } \begin{array}{c}\text { prodrugs } \\
\text { of } \\
\text { chloramphenicol, thiamphenicol, and } \\
\text { analogs thereof }\end{array}\end{array}$ & $(120)$ \\
\hline 7. & 06/09/2011 & US8012987B2 & $\begin{array}{l}\text { Indolo[2,1-b] quinazole- } 6,12 \text {-dione } \\
\text { antimalarial compounds and methods of } \\
\text { treating malaria therewith }\end{array}$ & $(121)$ \\
\hline 8. & 29/04/2010 & WO 047737 A2 & $\begin{array}{l}\text { Antimicrobial indoline compounds for } \\
\text { treatment of bacterial infections }\end{array}$ & $(122)$ \\
\hline 9. & $25 / 03 / 2010$ & WO032165A2 & Prodrugs of artemisinin & $(123)$ \\
\hline 10. & 30/01/2008 & EP1881974A2 & $\begin{array}{l}\text { Phosphonated fluoroquinolones, } \\
\text { antibacterial analogstherof, and methods } \\
\text { for the prevention and treatment of bone } \\
\text { and joint infections. }\end{array}$ & (124) \\
\hline 11. & $16 / 01 / 2007$ & US007163923B2 & Peptide deformylase activated prodrugs & $(125)$ \\
\hline 12. & 03/06/2004 & WO 046153A1 & Prodrug esters of ceftriaxone & $(126)$ \\
\hline 13. & $10 / 07 / 2003$ & US0130205A1 & $\begin{array}{l}\text { Novel pharmaceutical anti-infective agents } \\
\text { containing carbohydrate moieties and } \\
\text { methods of their preparation and use }\end{array}$ & $(127)$ \\
\hline 14. & $15 / 05 / 2003$ & US0092755 A1 & Novel prodrugs for antimicrobial amidines & $(128)$ \\
\hline 15. & $26 / 11 / 2002$ & US6486200B1 & Prodrugs for antimicrobial amidines & $(129)$ \\
\hline 16. & $22 / 05 / 2001$ & US6235728B1 & $\begin{array}{l}\text { Water soluble prodrugs of azole } \\
\text { compounds }\end{array}$ & $(130)$ \\
\hline 17. & $12 / 12 / 2000$ & US6159706A & $\begin{array}{l}\text { Application of enzyme prodrugs as anti- } \\
\text { infective agents }\end{array}$ & $(131)$ \\
\hline 18. & 23/03/1996 & WO015132A1 & Improved antiviral prodrugs & $(132)$ \\
\hline 19. & 08/11/1989 & EP 0340778A2 & $\begin{array}{l}\text { Prodrugs of 2',3' } \text {-Didehydro-2',3' } \\
\text { Dideoxynucleosides }\end{array}$ & (133) \\
\hline 20. & 22/01/1985 & US4495180 & Prodrugs of ARA-A an antiviral agent & $(134)$ \\
\hline 21. & 24/01/1984 & US4427582 & Antimicrobial disulfide prodrugs & $(135)$ \\
\hline
\end{tabular}




\section{REFERENCES}

1. Definition of "infection" from several medical dictionaries and medicinenet.com. www.medicinenet.com/script/main/art.asp?articleke $y=12923$. Accessed on June 06, 2014.

2. Kharb R, Yar MS, Sharma PC. New insights into chemistry and anti-infective potential of triazole scaffold. Curr Med Chem, 18(21):3265-3297, 2011.

3. Peleg AY, Hooper DC. Hospital-acquired infections due to Gramnegative bacteria. N Engl J Med, 362:1804-1813, 2010.

4. Filice GA, Nyman JA, Lexau C. Excess costs and utilization associated with methicillin resistance for patients with Staphylococcus aureus infection. Infect Control Hosp Epidemiol, 31:365-373, 2010.

5. Vincent JL, Rello J, Marshall J. International study of the prevalence and outcomes of infection in intensive care units. J A M A, 302:2323-2329, 2009.

6. Sharma PC, Jain A, Jain S. Fluoroquinolone antibacterials: a review on chemistry, microbiology and therapeutic prospects. Acta Pol Pharm, 66(6):587-604, 2009.

7. Dax, S.L.; Quinolone antibacterials, in Antibacterial Chemotherapeutic Agents. The R W Johnson Pharmaceutical Research Institute, Spring House, Pennsylvania, USA, Blackie Academic and Professional, London, pp 298-345, 1997.

8. Zhang T, Wu J, Chen S, Liu K, Lin Y, Guo H, Liu M. Synthesis and antibacterial activity of amino acid and dipeptide prodrugs of IMB-070593, a fluoroquinolone candidate. Molecules, 19: 68226837, 2014.

9. Dhaneshwara S, Tewari K, Joshi S, Godbole D, Ghosh P. Diglyceride prodrug strategy for enhancing the bioavailability of norfloxacin. Chem Phys Lipids, 164:307-313, 2011.

10. Dubey S, Jain V, Preethi GB. Evaluation of lipophilicity, antimicrobial activity and mutagenicity of some novel ester prodrugs of metronidazole. Indian J Chem, 48:1571-1576, 2009.

11. Dibama HM, Clarot I, Fontanay S, Salem AB, Finance MMC, Duval RE, Regnouf-de-Vains JB. Towards calixarene-based prodrugs: Drug release and antibacterial behavior of a water-soluble nalidixic acid/calix[4]arene ester adduct. Bioorg Med Chem Lett, 19:2679-2682, 2009.

12. Cassano R, Trombino S, Ferrarelli T, Cavalcanti P, Giraldi C, Lai F, Loy G, Picci N. Synthesis, characterization and in-vitro antitubercular activity of isoniazid-gelatin conjugate. J Pharm Pharmacol, 64(5):712-718, 2012.

13. Patil SJ, Shirote PJ. Prodrug approach: an effective solution to overcome side-effects. Int J Med Pharm Sci, 1(7):1-13, 2011.

14. Rao HSP. Capping drugs: Development of prodrugs. Resonance, 19-27, 2003.

15. Ettmayer P, Amidon GL, Clement B, Testa B. Lessons Learned from Marketed and Investigational Prodrugs. J Med Chem, 47(10): 2393-2404, 2004.

16. Han HK, Amidon GL. Targeted prodrug design to optimize drug delivery. AAPS Pharm Sci, 2(1):48$58,2000$.

17. Hu L. The prodrug approach to better targeting. Current drug discovery, 4(8):28-32, 2004.

18. Oliyai R, Stella VJ. Prodrugs of peptides and proteins for improved formulation and delivery. Annu Rev Pharmacol Toxicol, 32:521-44, 1993.

19. Bhosle D, Bharambe S, Gairola N, Dhaneshwar SS. Mutual prodrug concept: Fundamentals and applications. Ind J Pharm Sci, 68(3):286-294, 2006.

20. Tegeli VS, Thorat YS, Chougule GK, Shivsharan US, Gajeli GB, Kumbhar ST. Review on concepts and advances in prodrug technology. International Journal of Drug Formulation and Research, 1:32-57, 2010.

21. Damião MCFCB, Pasqualoto KFM, Polli MC, Parise-Filho R. To be drug or prodrug: structure property exploratory approach regarding oral bioavailability. J Pharm Pharm Sci. 17(4):532-540, 2014.

22. Zawilska JB, Wocieszak J, Olejniczak AB. Prodrugs: a challange for the drug development. Pharmacological reports, 65:1-14, 2013.

23. Huttunen KM, Raunio H, Rautio J. Prodrugs-from Serendipity to Rational Design. Pharmacol Rev, 63:750-771, 2011.

24. Rautio J. Prodrugs towards better drugs. Available on: $\quad$ http://mediaserver.aaps.org/meetings /09AM/Slides/11.11.09_Wed/406\%20AB/0900/Jark ko\%20Rautio.pdf. (Accessed on July 08, 2014)

25. Rautio J, Kumpulainen H, Heimbach T, Oliyai R, Oh D, Jrvinen T, Savolainen J. Prodrugs design and clinical applications. Drug discovery, 7:255-270, 2008.

26. Duggal S, Rathore P, Kanwar K. Prodrug: novel approaches for anti-inflammatory actions of NSAID's. Int J Pharm Technol, 4(1):1889-1908, 2012.

27. Nasa P, Phougat P. Prodrug: a novel approach of drug delivery. Int J Pharm Sci Rev Res, 25(1): 188191, 2014.

28. Saraf S, Saraf S, Chandrakar S. Prodrug: a sustained chemical drug delivery approach. Pharmainfo.net, 5(6):1-18, 2007.

29. Verma A, Verma B, Prajapati SK, Tripathi K. Prodrug as a chemical delivery system: a review. Asian J Research Chem, 2(2):100-103, 2009.

30. Bhattacharyya BK, Sen SK. Antibiotics business: a glimpse. Indian J Biotech, 5:471-476, 2006.

31. Sharma OP, Sharma PC, Jain S. Synthesis and bacterial evaluation of novel fluoroquinolone 
derivatives. International Conference on Bioscience, Biochemistry and Bioinformatics IPCBEE vol.5 (2011) (C) (2011) IACSIT Press, Singapore.

32. Khan SA, Asiri AM, Yusuf M. Synthesis and biological evaluation of some thiazolidinone derivatives of steroid as antibacterial agents. Eur J Med Chem, 44(6):2597-600, 2009.

33. Alwan SM, Abdul-Hafeedh H, Abdul-Wahab. Synthesis of new derivatives of Ceftazidime as possible Prodrugs. Iraqi J Pharm Sci, 22(2):35-45, 2013.

34. Abdul-Kadir MQ, AL-Ani NE, Alwan SM. Synthesis of new cyclic amines linked metronidazole derivatives as possible prodrugs. Iraqi J Pharm Sci, 18(2):1-7, 2009.

35. Sobczak M, Witkowska E, Olędzka E, Kolodziejski W. Synthesis and structural analysis of polyester prodrugs of norfloxacin. Molecules, 13:96-106, 2008.

36. Yar MS, Siddiqui AA, Ashraf Ali M, Manogran E. Design of targeted dosage form of ofloxacin. J Serb Chem Soc, 71(12):1269-1273, 2006.

37. Isoda $\mathrm{T}$, Ushirogochi $\mathrm{H}$, Satoh $\mathrm{K}$, Takasaki $\mathrm{T}$, Yamamura I, Sato C, Mihira A, Abe T, Tamai S, Yamamoto S, Kumagai T, Nagao Y. Synthesis and pharmacokinetic studies of prodrug esters for the development of oral carbapenem, L-084. J Antibiot, Z 59(4):241-247, 2006.

38. ÜnlÜsoy MC, Altanlar N, Ertan R. Synthesis and Antimicrobial Activities of Some New Flavonyl Pro-drug Esters of Ampicillin. Turk J Chem, 29:187-191, 2005.

39. Mishra S, Narain U, Mishra R, Misra K. Design, development and synthesis of mixed bioconjugates of piperic acid-glycine, curcumin-glycine/alanine and curcumin-glycine-piperic acid and their antibacterial and antifungal properties. Bioorg Med Chem, 13:1477-1486, 2005.

40. Hakimelahi GH, Moosavi-Movahedi AA, Saboury AA, Osetrov V, Khodarahmi GA, Shia KS. Carbapenem-based prodrugs. Design, synthesis, and biological evaluation of carbapenems. Eur J Med Chem, 40:339-349, 2005.

41. Moroni GN, Bogdanov PM, Briñón MC. Synthesis and in vitro antibacterial activity of novel 50-0analog derivatives of zidovudine as potential prodrugs. Nucleos Nucleot Nucl, 21(3):231-241, 2002.

42. Mori N, Kodama T, Sakai A, Suzuki T, Sugihara T, Yamaguchi S, Nishijima T, Aoki A, Toriya M, Kasai M, Hatano S, Kitagawa M, Yoshimi A, Nishimura K. AS-924, a novel, orally active, bifunctional prodrug of ceftizoxime: physicochemical properties, oral absorption in animals, and antibacterial activity. Int J Antimicrob Agents, 18:451-461, 2001.
43. Wei Y, Pei D. Activation of Antibacterial Prodrugs by Peptide Deformylase. Bioorg Med Chem Lett, 10:1073-1076, 2000.

44. Evans GB, Furneaux RH, Gravestock MB, Lynch GP, Scott GK. The synthesis and antibacterial activity of totarol derivatives. Part 1: modifications of ring $\mathrm{C}$ and prodrugs. Bioorg Med Chem, 7:19531964, 1999.

45. Bowden K, Izadi J. Prodrugs-part 2. Acylbenzoate esters of metronidazole. Eur J Med Chem, 32:9951000, 1997.

46. Tatar E, Küçükgüzel İ, Küçükgüzel ŞG, YılmazDemircan F, Clercq ED, Andrei G, Snoeck R, Pannecouque C, Şahin F, Bayrak ÖF. Synthesis, Anti-Tuberculosis and Antiviral Activity of Novel 2isonicotinoylhydrazono-5-arylidene-4-

thiazolidinones. International Journal of Drug Design and Discovery, 1(1):19-32, 2010.

47. World Health Organization. Available at: www.who.int/mediacentre/factsheets/fs104. (Accessed on Nov 20, 2014).

48. Sriram D, Yogeeswari P, Reddy SP. Synthesis of pyrazinamide mannich bases and its antitubercular properties. Bioorg Med Chem Lett, 16:2113-2116, 2006.

49. Fernandes JPS, Pavan FR, Leite CQF, Felli VMA. Synthesis and evaluation of a pyrazinoic acid prodrug in Mycobacterium tuberculosis. Saudi Pharm J, 22:376-380, 2014.

50. Teitelbaum AM, Meissner A, Harding RA, Wong CA, Aldrich CC, Remmel RP. Synthesis, pHdependent, and plasma stability of meropenem prodrugs for potential use against drug-resistant tuberculosis. Bioorg Med Chem, 21:5605-5617, 2013.

51. Uh E, Jackson ER, Jose GS, Maddox M, Lee RE, Lee RE, Boshoff HI, Dowda CS. Antibacterial and antitubercular activity of fosmidomycin, FR900098, and their lipophilic analogs. Bioorg Med Chem Lett, 21:6973-6976, 2011.

52. Qasir AJ, Jassim AD. Synthesis of mutual prodrug of p-amino salicylic acid (PAS) and isoniazid(INH), with possible enhancement physicochemical properties. Journal of al-nahrain university, 13(3):713, 2010.

53. Meng Q, Luo H, Liu Y, Li W, Zhang W, Yao Q. Synthesis and evaluation of carbamate prodrugs of SQ109 as antituberculosis agents. Bioorg Med Chem Lett, 19:2808-2810, 2009.

54. Rawat J, Jain PK, Ravichandran V, Agrawal RK. Synthesis and evaluation of mutual prodrugs of isoniazid, $p$-amino salicylic acid and ethambutol. ARKIVOC, 105-118, 2007.

55. Roseeuw E, Coessens V, Balazuc AM, Lagranderie M, Chavarot P, Pessina A, Neri MG, Schacht E, Marchal G, Dominique D. Synthesis, degradation 
and antimicrobial properties of targeted macromolecular prodrugs of norfloxacin. Antimicrob Agents Chemother, 47(11):3435-3441, 2003.

56. Thorsteinsson T, Másson M, Jarvinen T, Nevalainen T, Loftsson T. Cycloserine Fatty Acid Derivatives as Prodrugs: Synthesis, Degradation and in Vitro Skin Permeability. Chem Pharm Bull, 50(4):554-557, 2002.

57. Winter RW, Kelly JX, Smilkstein MJ, Dodean R, Hinrichs D, Riscoe MK. Antimalarial quinolones: synthesis, potency and mechanistic studies. Exp Parasitol, 118:487-497, 2008.

58. World Health Organization (WHO) (2014), World Malaria Report. Available at: www.who.int/malaria/publications/world_malaria_r eport_2014/wmr-2014-no-profiles. pdf. (Accessed on Jan 16, 2015).

59. Davanço MG, Aguiar ACC, Santos L Ad, Padilha EC, Campos ML, Andrade C Rd, Fonseca L Md, Santos J Ld, Chin CM, Krettli AU, Peccinini RG. Evaluation of antimalarial activity and toxicity of a new primaquine prodrug. Plos One, 9(8):1-10, 2014.

60. Milner E, Sousa J, Pybus B, Auschwitz J, Caridha D, Gardner S, Grauer K, Harris E, Hickman M, Kozar MP, Lee P, Leed S, Li Q, Melendez V, Moon J, Ngundam F, O'Neil M, Parriott S, Potter B, Sciotti R, Tangteung A, Dow GS. Ketotifen is an antimalarial prodrug of norketotifen with blood schizonticidal and liver-stage efficacy. Eur J Drug Metab Pharmacokinet, 37:17-22, 2012.

61. Caldarelli SA, Hamel M, Duckert JF, Ouattara M, Calas M, Maynadier M, Wein S, Périgaud C, Pellet A, Vial HJ, Peyrottes S. Disulfide Prodrugs of Albitiazolium (T3/SAR97276): Synthesis and Biological Activities. J Med Chem, 55:4619-4628, 2012.

62. Dubar F, Wintjens R, Martins-Duarte ES, Vommaro RC, De Souza W, Dive D, Pierrot C, Pradines B, Wohlkonig A, Khalife JBC. Ester prodrugs of ciprofloxacin as DNA-gyrase inhibitors: synthesis, antiparasitic evaluation and docking studies. Med Chem Commun, 2:430-435, 2011.

63. Dubar F, Anquetin G, Pradines B, Dive D, Khalife J, Biot C. Enhancement of the antimalarial activity of ciprofloxacin using a double prodrug/bioorganometallic approach. J Med Chem, 52:7954-7957, 2009.

64. Rajić Z, Kos G, Zorc B, Singh P, Singh S. Macromolecular prodrugs. Xii. Primaquine conjugates: synthesis and preliminary antimalarial evaluation. Acta pharm, 59:107-115, 2009.

65. Mishra S, Karmodiya K, Parasuraman P, Suroliaa A, Surolia N. Design, synthesis, and application of novel triclosan prodrugs as potential antimalarial and antibacterial agents. Bioorg Med Chem,
16:5536-5546, 2008.

66. Chambel P, Capela R, Lopes F, Iley J, Morais J, Gouveia L, Gomes JRB, Gomes P, Moreira R. Reactivity of imidazolidin-4-one derivatives of primaquine: implications for prodrug design. Tetrahedron, 62:9883-9891, 2006.

67. Xie LH, Li Q, Lin AJ, Smith K, Zhang J, Skillman DS. New potential antimalarial agents: therapeuticindex evaluation of pyrroloquinazolinediamine and its prodrugs in a rat model of severe malaria. Antimicrob Agents Chemother, 50(5):1649-1655, 2006.

68. Vial HJ, Wein S, Farenc C, Kocken C, Nicolas O, Ancelin ML, Bressolle F, Thomas A, Calas M. Prodrugs of bisthiazolium salts are orally potent antimalarials. Proc Natl Acad Sci, 101(43): 1545815463, 2004.

69. Vangapanduy S, Sachdeva S, Jain M, Singh S, Singh P, Kaul CL, Jain R. 8-Quinolinamines and their pro prodrug conjugates as potent blood-schizontocidal antimalarial agents. Bioorg Med Chem, 11:45574568, 2003.

70. Ortmann R, Wiesner J, Reichenberg A, Henschker D, Beck E, Jomaa H, Schlitzer M. Acyloxyalkyl ester prodrugs of FR900098 with improved in vivo antimalarial activity. Bioorg Med Chem Lett, 13:2163-2166, 2003.

71. Reichenberg A, Wiesner J, Weidemeyer C, Dreiseidler E, Sanderbrand S, Altincicek B, Beck E, Schlitzer M, Jomaa H. Diaryl ester prodrugs of FR900098 with improved in vivo antimalarial activity. Bioorg Med Chem Lett, 11:833-835, 2001.

72. Davioud-Charvet E, Delarue S, Biot C, Schwöbel B, Boehme CC, Müssigbrodt A, Maes L, Sergheraert C, Grellier P, Schirmer RH, Becker K. A prodrug form of a Plasmodium falciparum glutathione reductase inhibitor conjugated with a 4anilinoquinoline. J Med Chem, 44:4268-4276, 2001.

73. Kinyanjui SM, Mberu EK, Winstanley PA, Jacobus DP, Watkins WM. The antimalarial triazine wr99210 and the prodrug ps-15: folate reversal of in vitro activity against plasmodium falciparum and a non-antifolate mode of action of the prodrug. Am J Trop Med Hyg, 60(6):943-947, 1999.

74. Abdel-Aziza HA, Abdel-Wahab BF, Badria FA. Stereoselective synthesis and antiviaral activity of (1E,2Z,3E) -1-(Piperidin-1-yl)-1-(arylhydrazono)-2[(benzoyl/benzothiazol-2-oyl)hydrazono]-4-

(aryl1)but-3-enes. Arch Pharm Chem Life Sci, 343:152-159, 2010.

75. Dong SD, Lin CC, Schroeder M. Synthesis and evaluation of a new phosphorylated ribavirin prodrug. Antiviral Res, 99:18-26, 2013.

76. Li C, Quenelle DC, Prichard MN, Drach JC, Zemlicka J. Synthesis and antiviral activity of 6deoxycyclopropavir, a new prodrug of 
cyclopropavir. Bioorg Med Chem, 20:2669-2674, 2012.

77. Hiramath RD, Chandrashakhar MN, Sompur CK, Shattari AFAH, Maske AP, Shaikh R. Synthesis, invitro and bio-availability studies of acyclovir prodrug. Asian journal of pharmaceutical sciences and research, 1(1):38-48, 2011.

78. Katragadda S, Xiadong Z, Ravi TS, Mitra AK. Small neutral amino acid ester prodrugs of acyclovir targeting amino acid transporters on the cornea: possible antiviral agents against ocular hsv-1 infections. Ophthalmol Eye Dis, 2:43-56, 2010.

79. Wu Z, Drach JC, Prichard MN, Yanachkova M, Yanachkov I, Bowlin TL, Zemlicka J. L-valine ester of cyclopropavir: a new antiviral prodrug. Antiviral Chem Chemother, 20:37-46, 2009.

80. Shen W, Kim JS, Kish PE, Zhang J, Mitchell S, Gentry BG, Breitenbach JM, Drach JC, Hilfinger J. Design and synthesis of vidarabine prodrugs as antiviral agents. Bioorg Med Chem Lett, 19:792796, 2009.

81. Tang Y, Peng Z, Liu Z, Li Y, Jiang J, Li Z. Some new acyclic nucleotide analogues as antiviral prodrugs: Synthesis and bioactivities in vitro. Bioorg Med Chem Lett, 17:6350-6353, 2007.

82. Meerbach A, Meier C, Sauerbrei A, Meckel HM, Wutzler P. Antiviral activity of cyclosaligenyl prodrugs of the nucleoside analogue bromovinyldeoxyuridine against herpes viruses. Int $\mathrm{J}$ Antimicrob Agents, 27:423-430, 2006.

83. Song X, Vig BS, Lorenzi PL, Drach JC, Townsend LB, Amidon GL. Amino acid ester prodrugs of the antiviral agent 2-bromo, 5,6 dichloro-(1-Dribofuranosyl)benzimidazole as potential substrates of hPEPT1 transporter. J Med Chem, 48:1274-1277, 2005.

84. Anand BS, Hill JM, Dey S, Maruyama K, Bhattacharjee, PS, Myles ME, Nashed YE, Mitra AK. In vivo antiviral efficacy of a dipeptide acyclovir prodrug, val-val-acyclovir, against HSV-1 epithelial and stromal keratitis in the rabbit eye model. Invest Ophthalmol Vis Sci, 44(6):2529-2534, 2003.

85. Yang C, Gao H, Mitra AK. Chemical stability, enzymatic hydrolysis and nasal uptake of amino acid ester prodrugs of acyclovir. J Pharm Sci, 90(5):617624, 2001.

86. Harnden MR, Jarvest RL, Boyd MR, Sutton D, Hodge RAV. Prodrugs of the selective antiherpesvirus agent 9-[4 -hydroxy-3(hydroxymethyl)but-l-yl]guanin(eB RL 39123) with improved gastrointestinal absorption properties. J Med Chem, 32:1738-1743, 1989.

87. Colla L, Clercq ED, Busson R, Vanderhaeghe H. Synthesis and antiviral activity of water-soluble esters of acyclovir [ 9-[ (2-hydroxyet hoxy )met hyllguanine]. J Med Chem, 26:602-604, 1983.

88. Wiebe LI, Knaus EE. Concepts for the design of anti-HIV nucleoside prodrugs for treating cephalic HIV infection. Adv Drug Delivery Rev, 39:63-80, 1999.

89. Tatar E, Kü̧̈ükgüzel İ, Clercq ED, Krishnan R, Kaushik-Basu N. Synthesis, characterization and antiviral evaluation of 1,3-thiazolidine-4-one derivatives bearing L-valine side chain. Marmara Pharmaceutical Journal, 16:181-193, 2012.

90. World Health Organization, (WHO) Global Health Observatory data. Available at: www.who.int/gho/hiv/epidemic_status/deaths_text/e n/. (Accessed on Dec 20, 2014).

91. Palombo MS, Singh Y, Sinko PJ. Prodrug and conjugate drug delivery strategies for improving HIV/AIDS therapy. J Drug Del Sci Tech, 19(1):314, 2009.

92. Agarwal HK, Chhikara BS, Bhavaraju S, Mandal D, Doncel GF. Emtricitabine prodrugs with improved anti-HIV activity and cellular uptake. Mol Pharm, 10:467-476, 2013.

93. Guo H, Zhuang X, Qian K, Sun L, Wang X, Li H, Lee K, Xie L. Prodrug design,synthesis and pharmacokinetic evaluation of (30R, 40R)-3hydroxymethyl-4-methyl-30, 40-di-O-(S)camphanoyl-(p)-cis-khellactone. Acta Pharm Sin B, 2(2):213-219, 2012.

94. Qing-bin C, Gao-xiao Z, Pei Y, Yu-qiang Z. Synthesis and preliminary evaluation of anti-HIV agent AZT prodrug. Acta Pharm Sin, 46 (8):10151018, 2011.

95. Agrawal N, Chandrasekar MJN, Sara UVS, Rohini A. Poly (HEMA- Zidovudine) conjugate: a macromolecular prodrug for improvement in biopharmaceutical properties of the drug. Drug Deliv, 18(4):272-280, 2011.

96. Li H, Kim SW, Hong JH. Antiviral activity enhancement through the SATE prodrug of a $2^{\prime}$ modified 5' noncarbocyclic adenine analogue. Bull Korean Chem Soc, 31(8):2180-2184, 2010.

97. Yang L, Chen L, Zeng R, Li C, Qiao R, Hu L, Li Z. Synthesis, nanosizing and in vitro drug release of a novel anti-HIV polymeric prodrug: Chitosan-Oisopropyl-50-O-d4T monophosphate conjugate. Bioorg Med Chem, 18:117-123, 2010.

98. Liang Y, Sharon A, Grier JP, Rapp KL, Schinazi RF, Chu CK. 5'-O-Aliphatic and amino acid ester prodrugs of (-)- $\beta$-D-(2R,4R)-dioxolane-thymine. (DOT): Synthesis, anti-HIV activity, cytotoxicity and stability studies. Bioorg Med Chem, 17:14041409, 2009.

99. Roche D, Greiner J, Aubertin AM, Vierling P. Synthesis and in vitro biological evaluation of valine-containing prodrugs derived from clinically used HIV-protease inhibitors. Eur J Med Chem, 
43:1506-1518, 2008

100.Narayanasamy J, Pullagurla MR, Sharon A, Wang J, Schinazi RF, Chu CK. Synthesis and anti-HIV activity of (-)- $\beta$-D- $(2 R, 4 R)-1,3$-dioxolane-2,6diamino purine (DAPD) (amdoxovir) and (-)- $\beta$-D$(2 R, 4 R)$-1,3-dioxolane guanosine (DXG) prodrugs. Antiviral Res, 75:198-209, 2007.

101. Sriram D, Yogeeswari P, Myneedu NS, Saraswat V. Abacavir prodrugs: Microwave-assisted synthesis and their evaluation of anti-HIV activities. Bioorg Med Chem Lett, 16:2127-2129, 2006.

102.Mills R, WU GZ. Synthesis and evaluation of novel prodrugs of foscarnet and dideoxycytidine with a universal carrier compound comprising a chemiluminescent and a photochromic conjugate. J Pharm Sci, 93(5):1320-1336, 2004.

103. Hamada Y, Matsumoto H, Yamaguchi S, Kimura T, Hayashi Y, Kiso Y. Water-soluble prodrugs of dipeptide HIV protease inhibitors based on $\mathrm{O} \rightarrow \mathrm{N}$ intramolecular acyl migration: design, synthesis and kinetic study. Bioorg Med Chem, 12:159-170, 2004.

104.Miazga A, Poopeiko NE, Piasek A, Siwecker MA, Kulikowski T. 5'-O- ester prodrugs of potent and selective anti-HIV agent -2',3'-dideoxy -3'-fluoro-2thiothymidine ( $\mathrm{S}^{2} \mathrm{FLT}$ ): synthesis and antiHIV activity. Nucleos Nucleot Nucl, 22(5-8):805-807, 2003.

105. Rouquayrol M, Gaucher B, Greiner J, Aubertin AM, Vierling P, Guedj R. Synthesis and anti-HIV activity of glucose-containing prodrugs derived from saquinavir, indinavir and nelfinavir. Carbohydr Res, 336:161-180, 2001.

106. Matsumoto H, Matsuda T, Nakata S, Mitoguchi T, Kimura T, Hayashi Y, Kiso Y. Synthesis and biological evaluation of prodrug-type antiHIV agents: ester conjugates of carboxylic acid containing dipeptide HIV protease inhibitors and a reverse transcriptase inhibitors. Bioorg Med Chem, 9:417-430, 2001.

107.Farèse-Di Giorgio A, Rouquayrol M, Greiner J, Aubertin AM, Vierling P, Guedj R. Synthesis and anti-HIV activity of prodrugs derived from saquinavir and indinavir. Antiviral Chem Chemother, 11:97-110, 2000.

108. Machado J, Salomon H, Oliveira M, Tsoukas C, Krayevsky AA, Wainberg MA. Antiviral activity and resistance profile of phosphazid- a novel prodrug of AZT. Nucleosides and nucleotides, 18(45):901-906, 1999.

109. Badiee P, Hashemizadeh Z. Opportunistic invasive fungal infections: diagnosis and clinical management. Indian J Med Res, 139:195-204, 2014.

110. Shalini K, Kumar N, Drabu S, Sharma PK. Advances in synthetic approach to and antifungal activity of triazoles. Beilstein J Org Chem, 7:668677, 2011.
111. Sharma V, Bhatia R. Triazoles in antifungal therapy: a review. International journal of research in pharmaceutical and biomedical, 2(2):417-427, 2011.

112.Liu Y, Cao XF, Liu X, Cao YB, Chu WJ, Yang YS. Synthesis, pharmacokinetics and in vivo antifungal activity of the novel water-soluble prodrugs of itraconazole analogue YL-24. Chinese Chem Lett, 24:321-324, 2013.

113. Kagoshima Y, Mori M, Suzuki E, Shibayama T, Iida T, Kamai Y, Konosu T. Synthesis, cleavage, and antifungal activity of a number of novel, watersoluble ester prodrugs of antifungal triazole CS-758. Bioorg Med Chem Lett, 19:3559-3563, 2009.

114.Ueda Y, Matiskella JD, Golik J, Connolly TP, Hudyma TW, Venkatesh S, Dali M, Kang SH, Barbour N, Tejwani R, Varia S, Knipe J, Zheng M, Mathew M, Mosure K, Clark J, Lamb L, Medin I, Gao Q, Huang S, Chen CP, Bronson JJ. Phosphonooxymethyl prodrugs of the broad spectrum antifungal azole, ravuconazole: synthesis and biological properties. Bioorg Med Chem Lett, 13:3669-3672, 2003.

115.Ohwada J, Tsukazaki M, Hayase T, Oikawa N, Isshiki Y, Fukuda H, Mizuguchi E, Sakaitani M, Shiratori Y, Yamazaki T, Ichihara S, Umeda I, Shimma N. Design, synthesis and antifungal activity of a novel water soluble prodrug of antifungal triazole. Bioorg Med Chem Lett, 13:191-196, 2003.

116. Ohwada J, Murasaki C, Yamazaki T, Ichihara S, Umeda I, Shimmaa N. Synthesis of novel water soluble benzylazolium prodrugs of lipophilic azole antifungals. Bioorg Med Chem Lett, 12:2775-2780, 2002.

117.Sun X, Zeckner DJ, Zhang Y, Sachs RK, Current WL, Rodriguez M, Chen SH. Prodrugs of 3-amido bearing pseudomycin analogues: novel antifungal agents. Bioorg Med Chem Lett, 11:1881-1884, 2001.

118.Sun X, Zeckner DJ, Current WL, Boyer R, McMillian C, Yumibe N, Chen SH. NAcyloxymethyl Carbamate Linked Prodrugs of Pseudomycins are Novel Antifungal Agents. Bioorg Med Chem Lett, 11:1875-1879, 2001.

119.Rodriguez M J, Vasudevan V, Jamison JA, Borromeo PS, Turner WW. The synthesis of water soluble prodrugs analogs of echinocandin B. Bioorg Med Chem Lett, 9:1863-1868, 1999.

120.Ueda Y, Connolly TP, Kadow JF, Meanwell NA, Wang T, Chen CPH, Yeung KS, Zhang Z, Leahy DK, Pack SK, Soundararajan N, Sirard P, Levesque K, Thoraval D. Salts of prodrugs of piperazine and substituted piperidine antiviral agents. U.S. Patent 0,253,196, A1, September 26, 2013.

121. Vicente CLF, Ribeiro AEM, Torroaes VEA, Baptista DATS, Baltazar DCN. Pyrazinoic acid prodrugs activated by esterases of mycobacteria. 
W.O. Patent 0,842,14, A2, June 13, 2013.

122. Bapat AS, Mahesh G, Gokhale RS, Shah SS, Sengupta S, Prasad S, Ghosh S, Chawari RS, Arora N, Reddy S, Mishra M, Bajaj K. Conjugate-based antifungal and antibacterial prodrugs. W.O. Patent 1,779,86, A2, December 27, 2012.

123.Pogany S, Tanol M, Baltezor MJ. Decoquinate prodrugs. W.O. Patent 1,741,21, A2, December 20, 2012.

124. Appella D, Appella E, Inman JK, Miller JLM, Hayashi R, Wang D. Thioether prodrug compositions as anti-HIV and anti-retroviral agents. W.O. Patent 1,566,74, A2, December 15, 2011.

125.Glinka T.W. Water soluble prodrugs of chloramphenicol, thiamphenicol, and analogs thereof. U.S. Patent 8,044,230, B2, October 25, 2011.

126.Pitzer KK, Scovill JP, Kyle DE, Gerena L. Indolo[2,1-b] quinazole-6,12-dione antimalarial compounds and methods of treating malaria therewith. U.S. Patent 8,012,987, B2, September 06, 2011.

127.Gordeev MF, Yuan Z, Liu J, Wang Q. Antimicrobial indoline compounds for treatment of bacterial infections. W.O. Patent 0,477,37, A2, April 29, 2010.

128. Breytenbach JC, N'da DD, Ashton M. Prodrugs of artemisinin. W.O. Patent 0,321,65, A2, March 25, 2010.

129.Delorme D, Houghton T, Kang T, Tanaka K, Lafontaine Y, Dietrich E, Rafi FA. Phosphonated fluoroquinolones, antibacterial analogs thereof, and methods for the prevention and treatment of bone and joint infections. E.P. Patent 1,881,974, A2, January 30, 2008.

130.Sergeeva MV, Doppalapudi VR. Peptide deformylase activated prodrugs. U.S. Patent 7,163,923, B2, January 16, 2007.

131. Aryan RC, Kumar Y, Raina V. Prodrug esters of ceftriaxone. W.O. Patent 0,461,53, A1, June 3, 2004.

132. Christian ST. Novel pharmaceutical anti-infective agents containing carbohydrate moieties and methods of their preparation and use. U.S. Patent 0,130,205, A1, July 10, 2003.

133. Boykin DW, Rahmathullah MS, Tidwell RR, Hall JE. Novel prodrugs for antimicrobial amidines. U.S. Patent 0,092,755, A1, May 15, 2003.

134.Boykin DW, Rahmathullah MS, Tidwell RR, Hall JE. Prodrugs for antimicrobial amidines. U.S. Patent 6,486,200, B1, November 26, 2002.

135.Golik J, Matiskella JD, Ueda Y. Water soluble prodrugs of azole compounds. U.S. Patent 6,235,728, B1, May 22, 2001.

136. Shepard HM. Application of enzyme prodrugs as anti-infective agents. U.S. Patent 6,159,706, A, December 12, 2000.

137.Hostetler KY, Kini GD. Improved antiviral prodrugs. W.O. Patent 0,151,32, A1, March 23, 1996.

138. Starrett JE, Mansuri MM, Martin JC. Prodrugs of 2',3'-didehydro-2',3' dideoxynucleosides. E.P. Patent 0,340,778, A2, November, 1989.

139. Alexander J. Prodrugs of ARA-A an antiviral agent. U.S. Patent 4,495,180, January 22, 1985.

140.Gilvarg C, Kingsbury WD. Antimicrobial disulfide prodrugs. U.S. Patent 4,427,582, January 24, 1984. 